\title{
Chemistry of 4-oxo-4H-1-benzopyran-3-carbonitrile
}

\author{
Chandra Kanta Ghosh ${ }^{* a}$ and Amarnath Chakraborty ${ }^{\mathrm{b}}$ \\ ${ }^{a}$ Organic Chemistry Laboratory, Department of Biochemistry, Calcutta University, Kolkata \\ 700019, India (since retired) \\ ${ }^{b}$ Department of Basic Sciences and Humanities, Institute of Engineering and Management, \\ Salt Lake Electronics Complex, Sector-5, Kolkata 700091, India \\ Email:ghosh.chandrakanta@gmail.com; amarprem@gmail.com
}

DOI: $\underline{\text { http://dx.doi.org/10.3998/ark.5550190.p009.273 }}$

\begin{abstract}
The review article, primarily designed to complement an earlier one (J. Heterocycl. Chem. 2005, $42,1035-1042)$, gives a comprehensive survey of the synthesis and chemistry of the title nitrile covering the literature published during 2005-2014.
\end{abstract}

Keywords: 4-Oxo-4H-1-benzopyran-3-carbonitrile, radical addition, nucleophilic addition, azaand oxa-Michael allylation, cycloaddition, carbocyanation

\section{Table of Contents}

1. Introduction

2. Synthesis

3. Radical Addition

4. Transformation of the Nitrile Group of 3-Cyanochromone

5. Reaction with Nitrogeneous Nucleophiles

5.1. Reaction with ammonia

5.2. Reaction with primary amines

5.3. Reaction with hydrazines

5.4. Reaction with hydroxylamine

6. Reaction with Carbon Nucleophiles

6.1. Reaction with active methyl compounds

6.2. Reaction with active methylene compounds

6.3. Reaction with enamines

6.4. Reaction with pyridinium phenacylide

6.5. Reaction with 1,3-bis-silyl ethers of 1,3-dicarbonyl compounds

7. Aza- and Oxa- Michael - Allylation 
8. Cycloaddition Reactions

8.1. [3+2] Dipolar cycloaddition

8.2. [4+2] Cycloaddition

9. 3-Cyanochromone as a Component in One-pot Multicomponent Synthesis

10. Carbocyanation of Alkyne with 3-Cyanochromone

11. Conclusions

12. References

\section{Introduction}

The uniqueness of the title benzopyran (trivial name: 3 -cyanochromone) $\mathbf{1}$, because of its diverse functionalities (an endocyclic olefinic bond with a keto and a nitrile functionalities at one end and a nucleofugal phenoxy group at the other end), its capability to assume a pyrylium betaine structure in the presence of an appropriate reagent and its 'chemical equivalence' to 2-amino-3formylchromone 2 under certain reaction conditions, is mentioned in our earlier review article ${ }^{1}$ covering the literature on its synthesis and reactions reported up to 2004. Earlier syntheses reported up to 1986 of different heterocycles fused with the 2,3-bond of [1]benzopyran from 3cyanochromone 1 or its equivalent 2-amino-3-formylchromone have been compiled. ${ }^{2}$ A critical account $^{3}$ of the reactions of the nitrile 1 with amines, hydrazines and hydroxylamine appeared in 2012. The present article, primarily designed to complement our earlier one, ${ }^{1}$ is a comprehensive survey of the chemistry of 3-cyanochromone 1 covering the literature published from 2005 2014. Some earlier works which have later been either adversely criticized or rectified or are helpful for a better understanding of the present write-up are briefly referred to. Patented works and reactions of 2-substituted 3-cyanochromone are excluded, and the biological properties of the reported compounds are less emphasized. In this manuscript the 4-oxo-4H-1-benzopyran-3-yl moiety is abbreviated as 'Chr' so that the title nitrile 1 may be represented by ChrCN. Alkyl, alkoxy and halogeno substituents in the benzene ring of chromone remain unaffected in most of the reactions described here for the unsubstituted 3-cyanochromone. The reactions of the nitrile $\mathbf{1}$ are described here in the following sections and subsections based on the type of reactions and nature of the reagents. It is worth mentioning here that a closely related review article 'Chemistry and application of 4-oxo-4H-1-benzopyran-3-carboxaldehyde' has been recently published by the present authors. ${ }^{4}$

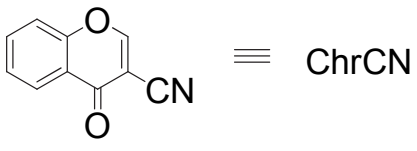

1

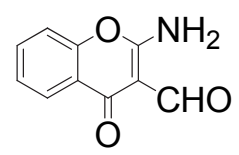

2

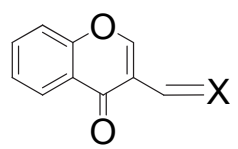

$3 \mathrm{X}=\mathrm{O}$

$4 \mathrm{X}=\mathrm{NOH}$

$5 \mathrm{X}=\operatorname{NOR}(R=$ alkyl or aryl) 


\section{Synthesis}

3-Cyanochromone can be prepared from 4-oxo-4H-1-benzopyran-3-carboxaldehyde 3 via its oxime $4^{5-8}$ or oxime $O$-alkyl (or aryl) ether 5. ${ }^{9-11}$ A convenient synthesis of 1 involves VilsmeierHaack reaction of 2-hydroxyacetophenone with $\mathrm{DMF}$ and $\mathrm{POCl}_{3}$ at $0{ }^{\circ} \mathrm{C}$ and subsequent treatment of the reaction mixture in situ with $\mathrm{NH}_{2} \mathrm{OH} . \mathrm{HCl}$ at ambient temperature. ${ }^{12}$

3-Bromochromanone 6 has been converted into 3-cyanochromone 1. The former on KHMDS enhanced $\mathrm{SmI}_{2}$-mediated cyanation by tosyl cyanide gives 3-cyanochromanone 7 which on dehydrogenation by DDQ affords the nitrile $\mathbf{1}$ (Scheme 1). ${ }^{13}$

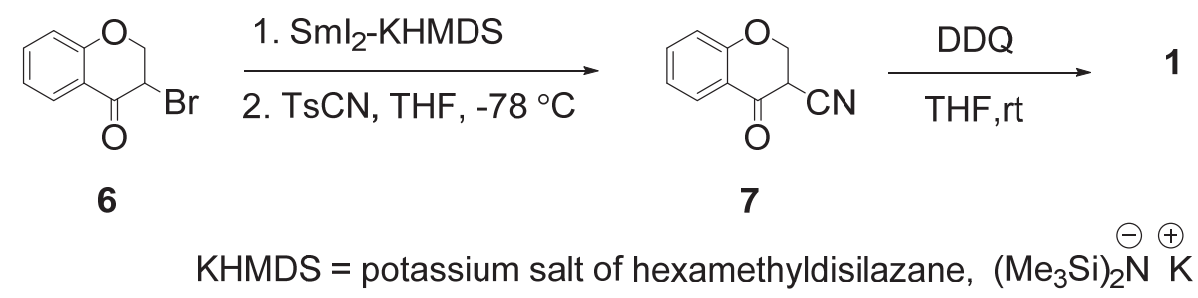

Scheme 1

\section{Radical Addition}

An alkyl iodide such as $\mathbf{8}(\mathrm{R}=$ ethyl, $i$-Pr, $t$-butyl, cyclopentyl, cyclohexyl) undergoes radical addition to the pyran 2,3-olefinic bond of $\mathbf{1}$ in the presence of triethylborane and oxygen, giving in an excellent overall yield (81-94\%) a diastereoisomeric mixture of the chromanone 9, the trans-isomer predominating over the cis-isomer (Scheme 2); the diastereoselectivity is not improved by carrying out the reaction at low $\left(\sim 40{ }^{\circ} \mathrm{C}\right)$ temperature. ${ }^{14}$

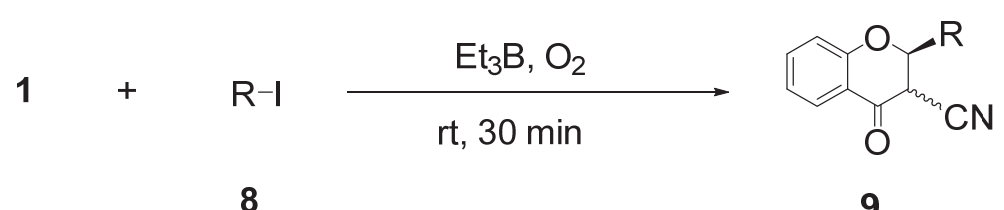

\section{Scheme 2}

\section{Transformation of the Nitrile Group of 3-Cyanochromone}

Transformation of $\mathrm{ChrCN}$ to chromone-3-carboxamide, -3- $\mathrm{N}$-t-butylcarboxamide and the 3carboxylic acid has already been mentioned. ${ }^{1}$ Ibrahim $^{15}$ prepared the carboxamide $\mathbf{1 0}$ by treatment of a suspension of 3-formylchromone in carbon tetrachloride with NBS under UV irradiation followed by evaporation of the solvent and quenching the reaction mixture with ammonia, and subjected it to various transformations (Scheme 3). Thus, carboxamide 10 with aqueous $\mathrm{NaOH}(1 \mathrm{M})$ rearranges to 4-hydroxycoumarin 12 via 11 , with $\mathrm{RNH}_{2}(\mathrm{R}=\mathrm{Me}, \mathrm{Et})$ in ethanol the 4-aminomethylenecoumarin 13, and with $\mathrm{MeONa}$ the azaxanthone derivative 14. 1,2- 
Addition of hydroxylamine to nitrile functionality of $\mathrm{ChrCN}$ is mentioned elsewhere (vide section 5.4)

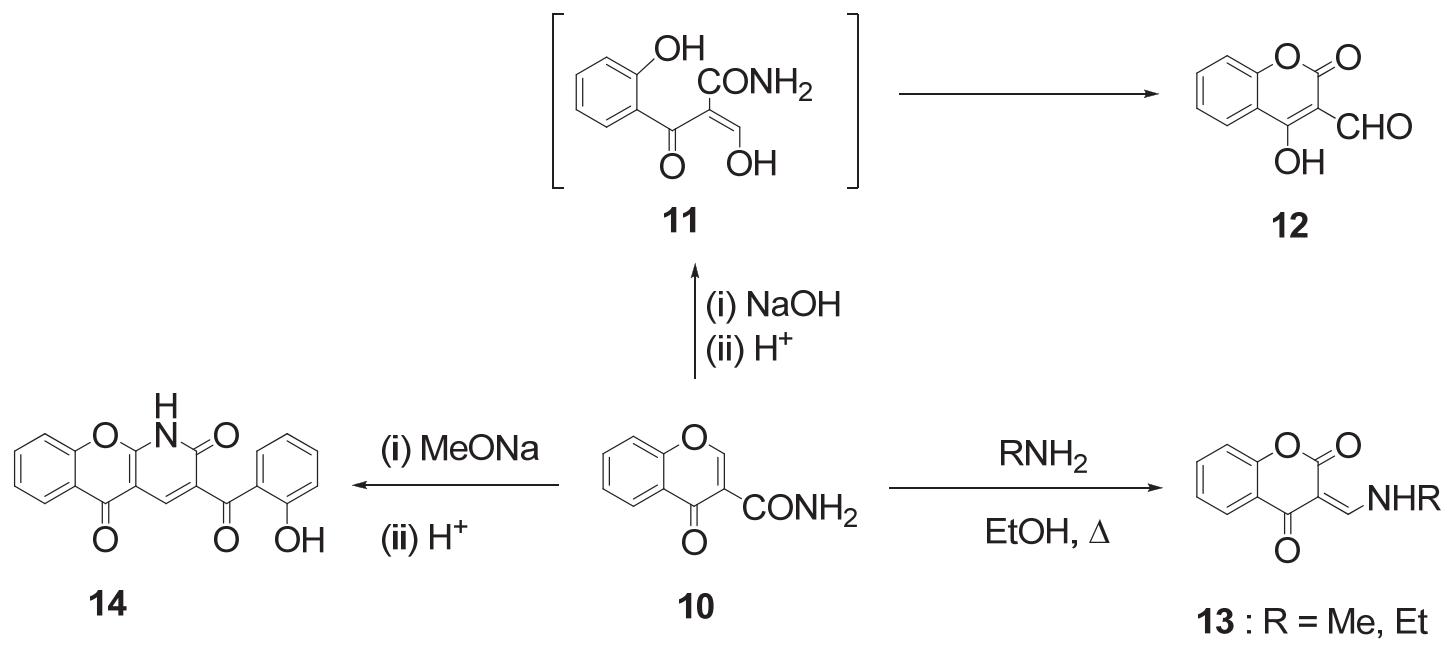

\section{Scheme 3}

\section{Reaction with Nitrogeneous Nucleophiles}

\subsection{Reaction with ammonia}

$\mathrm{ChrCN}$ is prone to form the aldehyde $\mathbf{2}$ even under slightly alkaline conditions. ChrCN in ethanol containing a few drops of aqueous ammonia on warming produces the aldehyde 2. ChrCN when heated with ammonium acetate in acetic acid under reflux affords the self-condensation product 18 which is also obtained on refluxing the aldehyde 2 in acetic acid. ${ }^{16}$ Here the aminochromone $15(\mathrm{X}=\mathrm{NH}$ or $\mathrm{O})$ condenses with itself through a domino Michael - retro-Michael heterocyclization reaction sequence giving the chromenopyrimidine 18 (Scheme 4).

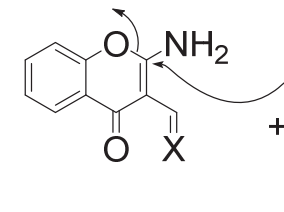

15

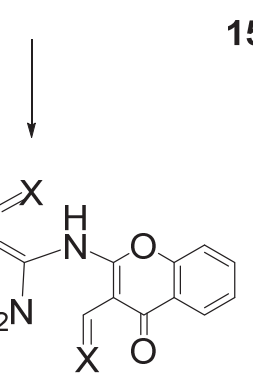

16<smiles></smiles>

18

$-2 \mathrm{XH}_{2}$

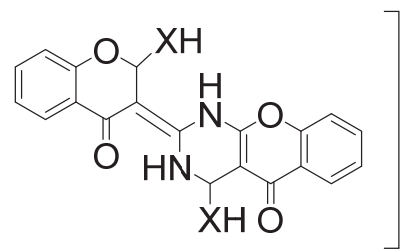

17

\section{Scheme 4}




\subsection{Reaction with primary amines}

The nature of the products resulting from the reaction of $\mathrm{ChrCN}$ with a primary amine depends on the stoichiometry of the reactants as well as the reaction conditions; a minor variation in the reaction conditions may drastically change the reaction course. We obtained 2-amino-3formylchromone 2 (45\%) together with 2-methylenetetrahydro-imidazole 22 (15\%) by refluxing an equimolar mixture of $\mathbf{1}$ and ethylenediamine $\mathbf{1 9}$ in ethanol for $3 \mathrm{~h},{ }^{16}$ but got the diazocene $\mathbf{2 7}$, a dimer of $\mathrm{ChrCN}$, by just warming an ethanolic solution of a 1:0.5 molar mixture of $\mathbf{1}$ and 19 for 10 min. ${ }^{17}$ In contrast, heating $\mathrm{ChrCN}$ ( 1 equiv) with ethylenediamine $(0.5$ equiv) in ethanol for $10 \mathrm{~min}$ is reported to produce the bis-imine 29. ${ }^{18}$ All these products 2, 22, 27 and 29 have been well characterized by analytical and spectral data beyond any doubt; hence the Russian group's terse comment ${ }^{18}$ as the reported ${ }^{17}$ diazocene $\mathbf{2 7}$ being in fact the bis-imine 29 is unjustified.

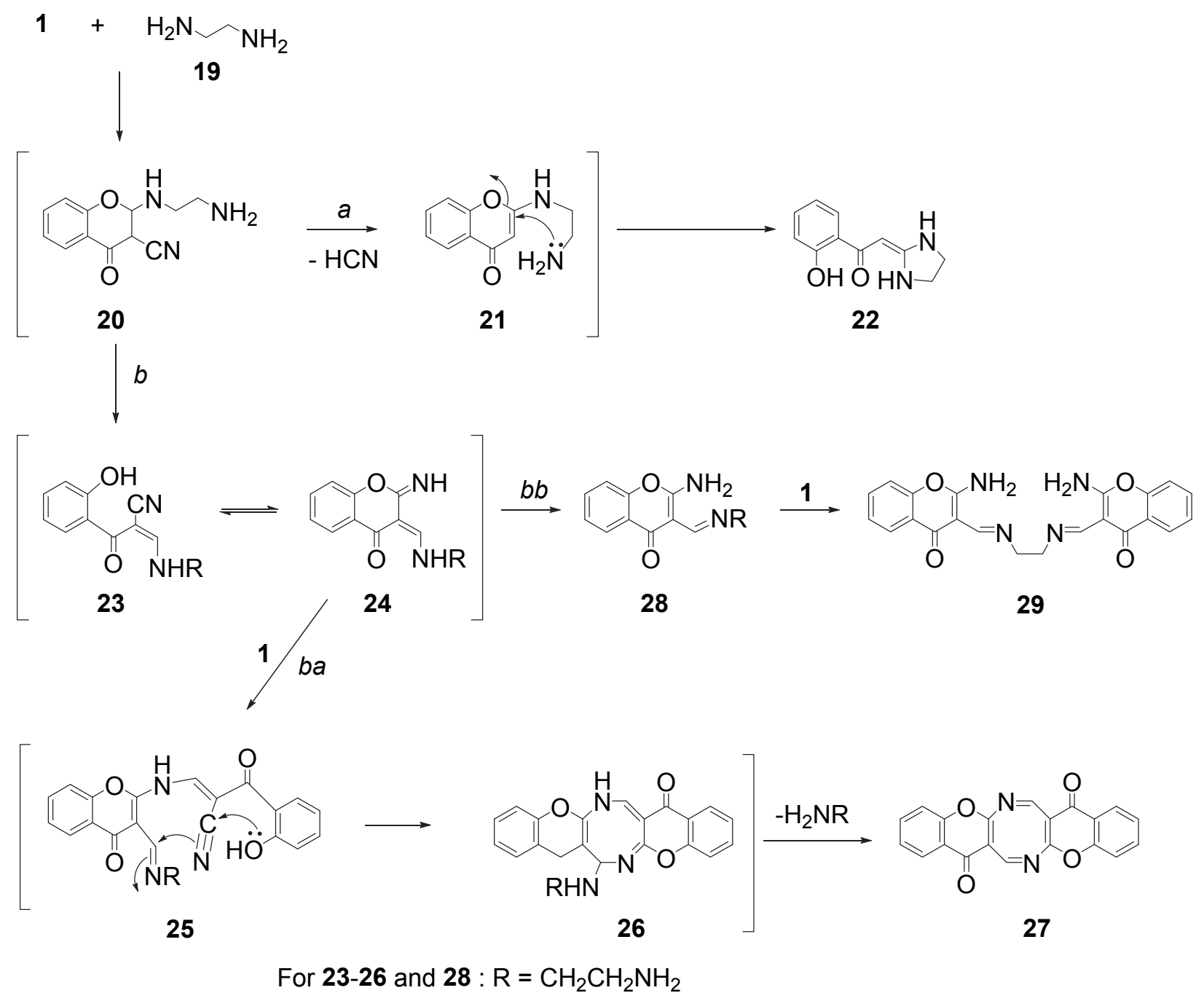

\section{Scheme 5}


Plausible mechanisms for the formation of all the above named products are given in Scheme 5. The diamine 19 undergoes aza-Michael addition to the $\alpha, \beta$-unsaturated nitrile 1; the adduct 20 by a base catalyzed elimination of HCN gives 21 (path $a$ ), the diamine 19 or the adduct 20 itself functioning as the base. The intermediate 21 by an intramolecular 1,4-addition with concomitant opening of the pyran ring gives the imidazole $\mathbf{2 2}$. The adduct $\mathbf{2 0}$ also undergoes retro-Michael to give $\mathbf{2 3}$ (path $b$ ), its cyclic isomer $\mathbf{2 4}$ taking up two different reaction courses. It functions as a nucleophile to a second molecule of $\mathrm{ChrCN}$ to give ultimately the diazocene 27 via 25 and $\mathbf{2 6}$ through an ANRORC mechanism (path $b a$ ). A 1,5-Hydrogen shift in the imino-enamine $\mathbf{2 4}$ leads to $\mathbf{2 8}$ that reacts with a second $\mathrm{ChrCN}$ molecule giving bischromone 29 again through an ANRORC mechanism (path $b b$ ). The formation of 2aminochromone $\mathbf{2}$ as the major product obtained by refluxing $\mathrm{ChrCN}$ with ethylenediamine in ethanol ${ }^{16}$ may involve hydrolysis of any or/and all of the compounds 27-29.

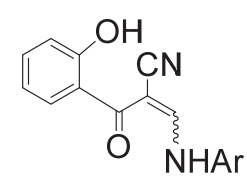

30

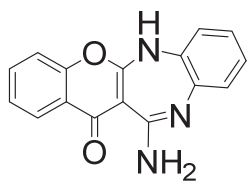

36

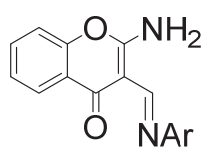

31

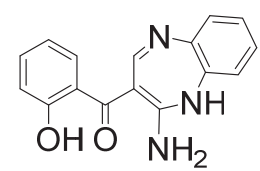

37

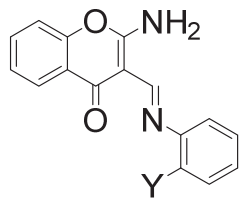

$32 \mathrm{Y}=\mathrm{NH}_{2}$ $33 \mathrm{Y}=\mathrm{OH}$

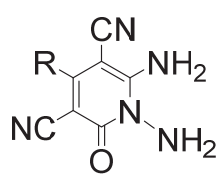

38

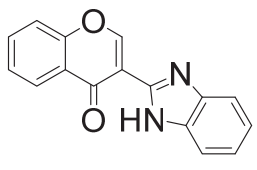

34

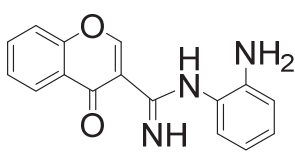

35

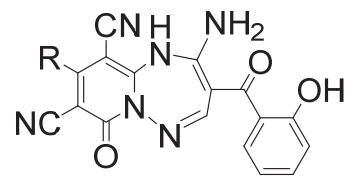

39

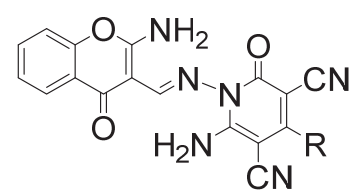

40

For 38-40 : R = p-chlorophenyl, 5-methyl-4-oxo-4H-1-benzopyran-3-yl

An aromatic primary amine as $\mathrm{ArNH}_{2}(\mathrm{Ar}=$ phenyl or substituted phenyl) with ChrCN in refluxing benzene gives in varying proportions the acrylonitrile $\mathbf{3 0}(Z, E$-mixture) and the Schiff base 31, the latter being formed exclusively in the presence of a few drops of triethylamine in the reaction medium. ${ }^{18,19}$ The compound $31\left(\mathrm{Ar}=4-\mathrm{MeC}_{6} \mathrm{H}_{4}\right)$ is, however, obtained by reacting $\mathrm{ChrCN}$ with $p$-toluidine in refluxing benzene. ${ }^{20} \mathrm{ChrCN}$ reacts similarly with $o$-phenylenediamine and $o$-aminophenol yielding $\mathbf{3 2}$ and 33, respectively. Transformation of $\mathbf{3 2}$ in boiling acetic acid to 1-benzopyran-3-ylimidazole $\mathbf{3 4}$ has been rationalized. ${ }^{3,19}$ The erroneous structures $\mathbf{3 5}$ and $\mathbf{3 6}$, the former proposed to arise from 1 and $o$-phenylenediamine in hot ethanol and the latter by cyclization of the former and subsequent air oxidation, ${ }^{16}$ have been duly rectified by Sosnovskikh et al. ${ }^{3,19}$ as $\mathbf{3 2}$ and 34, respectively. The structure 37 assigned to the product similarly obtained by Risitano et al. ${ }^{21}$ from 1 and $o$-phenylenediamine should also be rectified as 32. In light of these data, the 1,2,4-triazine structure 39 proposed for the product obtained by refluxing $\mathrm{ChrCN}$ with 1,6-diamino-2-oxo-1,2-dihydropyridine 38 ( $\mathrm{R}=p$-chlorophenyl, 5methyl-4-oxo-4H-1-benzopyran-3-yl) in $\mathrm{DMF}^{22-24}$ deserves further scrutiny; it may be assigned 
the structure 40. The pyranopyrimidine 18 is obtained by heating 33 in $\mathrm{AcOH}^{19}$ as well as 31 (Ar $\left.=4-\mathrm{MeC}_{6} \mathrm{H}_{4}\right)$ in $\mathrm{DMF}^{20}$ through a mechanism as depicted in Scheme 4, $\mathrm{X}$ in 15-17 representing the appropriate NAr.

\subsection{Reaction with hydrazines}

Our contention of 1,2-addition of phenylhydrazine $\mathbf{4 1}$ to the nitrile functionality of $\mathrm{ChrCN}$ and convertibility of the iminohydrazine adduct 42 to 3 -aminopyrazole $\mathbf{4 3}$ (Scheme 6 - path $a)^{25}$ has been convincingly refuted by Sosnovskikh et al. ${ }^{3,26}$ who have obtained a mixture of hydrazone 45 and 5-aminopyrazole 46 from the same reactants and under identical conditions evidently via the intermediate 44 (resulting from a domino Michael - retro-Michael reaction) (Scheme 6, path $b$ ); the hydrazone $\mathbf{4 5}$ is the exclusive product when the reaction is carried out in benzene or benzene-triethylamine and it can be converted to $\mathbf{4 6}$ under conditions as shown in Scheme 6. An acetic acid solution of 1 and $\mathbf{4 1}$ on heating affords via $\mathbf{4 4}$ the chromenopyrazolone $47 .^{26}$

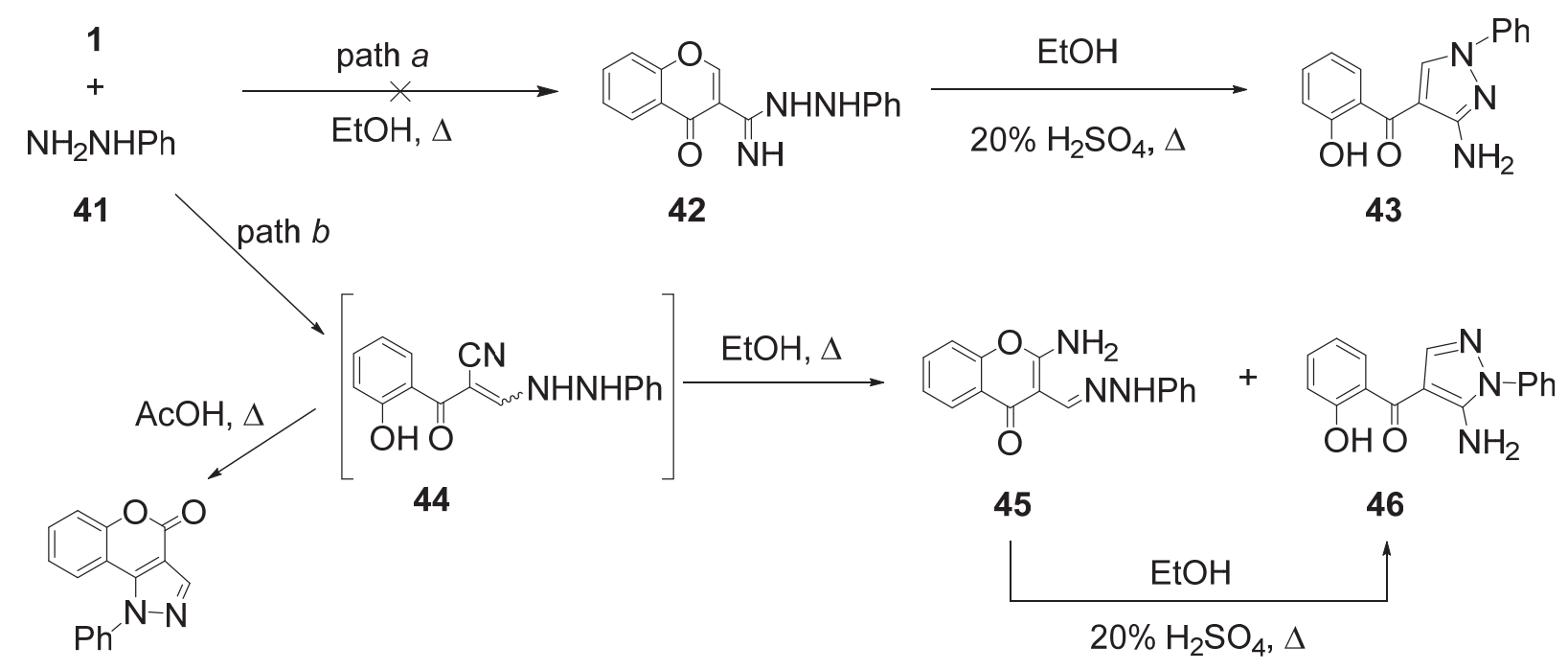

47

\section{Scheme 6}

The nitrile 1 with methylhydrazine in boiling $\mathrm{C}_{6} \mathrm{H}_{6}$ gives the pyrazole $\mathbf{4 8}$ admixed with a little amount of its isomer 49, whereas the same mixture in boiling acetic acid forms the pyrazolocoumarin 50 which is also obtainable by digesting 48 in acetic acid. ${ }^{26}$ A mixture of $\mathrm{ChrCN}$ and $N, N$-dimethylhydrazine in refluxing benzene forms the hydrazone 51 that in DMF heated under reflux undergoes self-condensation to the diazocene $27 .^{20}$ 
<smiles>Cn1cc(C#N)c(-c2ccccc2O)n1</smiles>

48

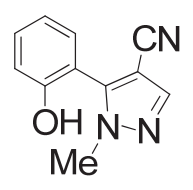

49

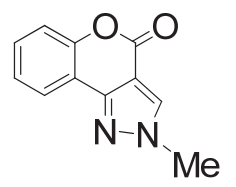

50<smiles>CN/N=C/c1c(N)oc2ccccc2c1=O</smiles>

51

\subsection{Reaction with hydroxylamine}

We have reported the formation of the hydroxylamino-imine $\mathbf{5 2}$ by reacting $\mathrm{ChrCN}$ with an equivalent amount of $\mathrm{NH}_{2} \mathrm{OH} . \mathrm{HCl}$ in ethanol containing $\mathrm{NaOAc}^{25}$ As per a polish group's report $^{27,28}$ the same reaction in the presence of alkali gives in addition to the oxime $\mathbf{5 4}$ another compound assigned as $\mathbf{5 3}$ on the basis of a doubtful mechanism. A Russian group ${ }^{3,29,30}$ have asserted that the initially formed amino-aldoxime $\mathbf{5 4}$ under alkaline condition leads via $\mathbf{5 5}$ and $\mathbf{5 6}$ to 2-amino-3-carbamoylchromone 57 (Scheme 7), its structure being confirmed by detailed spectral studies. The chromone 57 on further treatment with $\mathrm{NH}_{2} \mathrm{OH}$ gives the chroman-2,4dione 60 through 58 and 59. In the conversion $(59 \rightarrow 60), \mathrm{NH}_{2} \mathrm{OH}$ brings about reductive cleavage of $\mathrm{N}-\mathrm{O}$ bond of the isoxazole 59. The diamine $\mathbf{6 0}$ on acetylation forms an $E$, Z- mixture of the monoacetate 61 (Scheme 7).

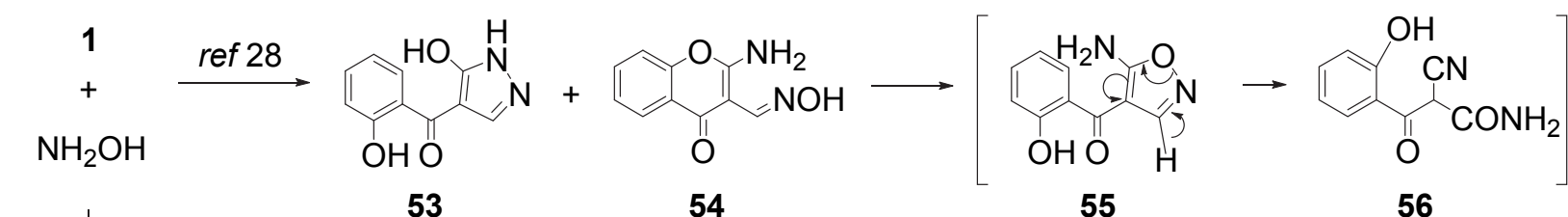

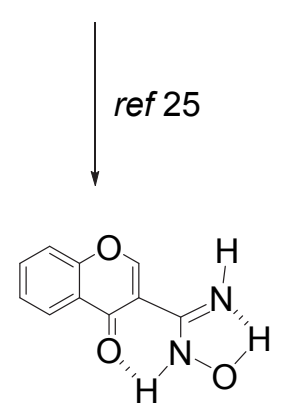

52

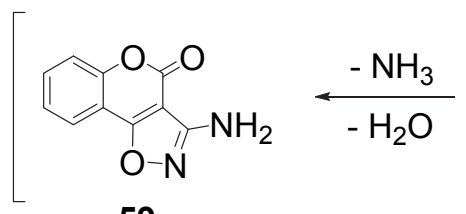

59
55

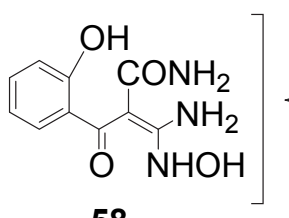

58<smiles>NC(=O)c1c(N)oc2ccc(O)cc2c1=O</smiles>

57<smiles>COc1ccccc1C(=O)C(N)N</smiles>

60
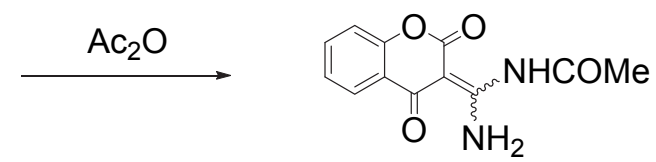

61

\section{Scheme 7}

A careful scrutiny of the reported IR and ${ }^{1} \mathrm{H}-\mathrm{NMR}$ (DMSO- $d_{6}$ ) of the three compounds 52, 53 and 57 reveals that the first two compounds show identical IR and ${ }^{1} \mathrm{H}-\mathrm{NMR}$ spectra 
having three exchangeable hydrogens whereas $\mathbf{5 7}$ four exchangeable hydrogens. We feel that the so called compound $\mathbf{5 3}$ is indeed 52, particularly its mass spectral fragmentation [m/e: 204 (27\%, $\left.\mathrm{M}^{+}\right), 171\left(100, \mathrm{M}-\mathrm{NH}_{2} \mathrm{OH}\right)$ and $\left.144\left(19, \mathrm{M}-\mathrm{NH}_{2} \mathrm{OH}-\mathrm{HCN}\right)\right]$ indicating it to arise from 1,2addition of $\mathrm{NH}_{2} \mathrm{OH}$ to cyano group of ChrCN. So the Russian group's assertion ${ }^{3,29,30}$ that the structures $\mathbf{5 2}$ and $\mathbf{5 3}$ be rectified as $\mathbf{5 7}$ is not worth consideration. Furthermore, the chromone $\mathbf{5 2}$ in the presence of excess $\mathrm{NH}_{2} \mathrm{OH}$ is likely to give the oxime $\mathbf{5 4}$ through the intermediates $\mathbf{A}$ and B (Scheme 8) and ultimately to 60 via 57 (Scheme 7). That is why Sosnovskikh ${ }^{29,30}$ failed to isolate the compound $\mathbf{5 2}$.

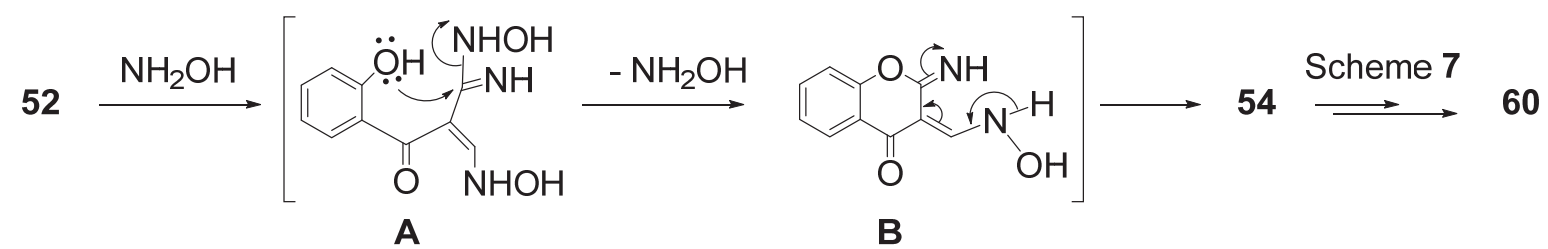

\section{Scheme 8}

\section{Reaction with Carbon Nucleophiles}

\subsection{Reaction with active methyl compounds}

The intermediate $\mathbf{6 3}$ resulting from the base catalyzed Michael - retro-Michael reaction of the hetaryl methyl ketone $\mathbf{6 2}$ with the nitrile 1 undergoes heterocyclization to 1-benzopyrano[2,3b]pyridine 64 (Scheme 9). ${ }^{31}$

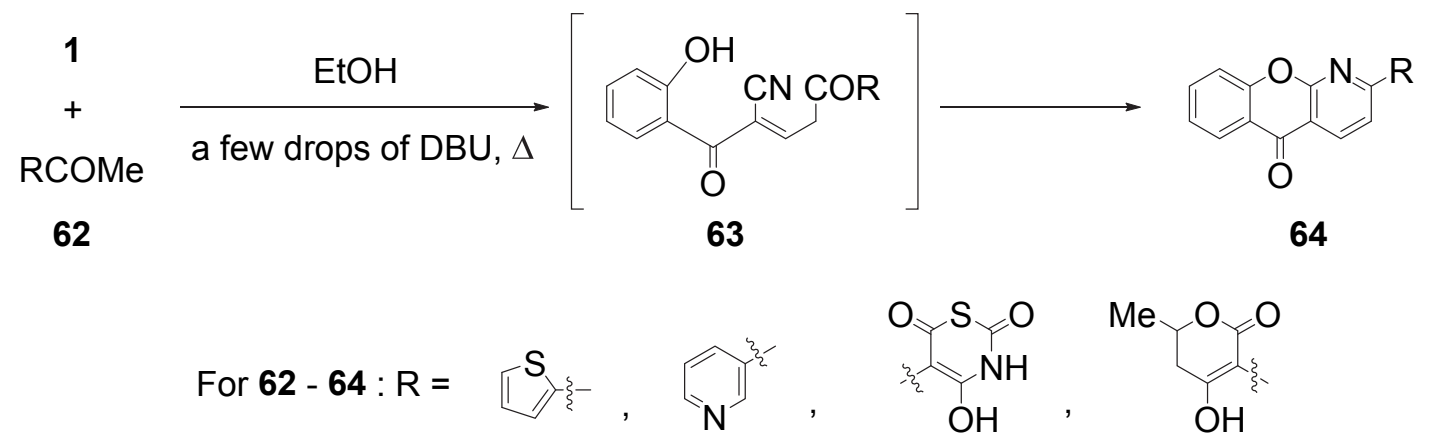

\section{Scheme 9}

The reaction of ChrCN with diacetylresorcinol 65 depends on the stoichiometry of the reactants to give either 3-aryl-4-azaxanthone $\mathbf{6 6}$ or bis-azaxanthone 67 (Scheme 10). ${ }^{31}$ 


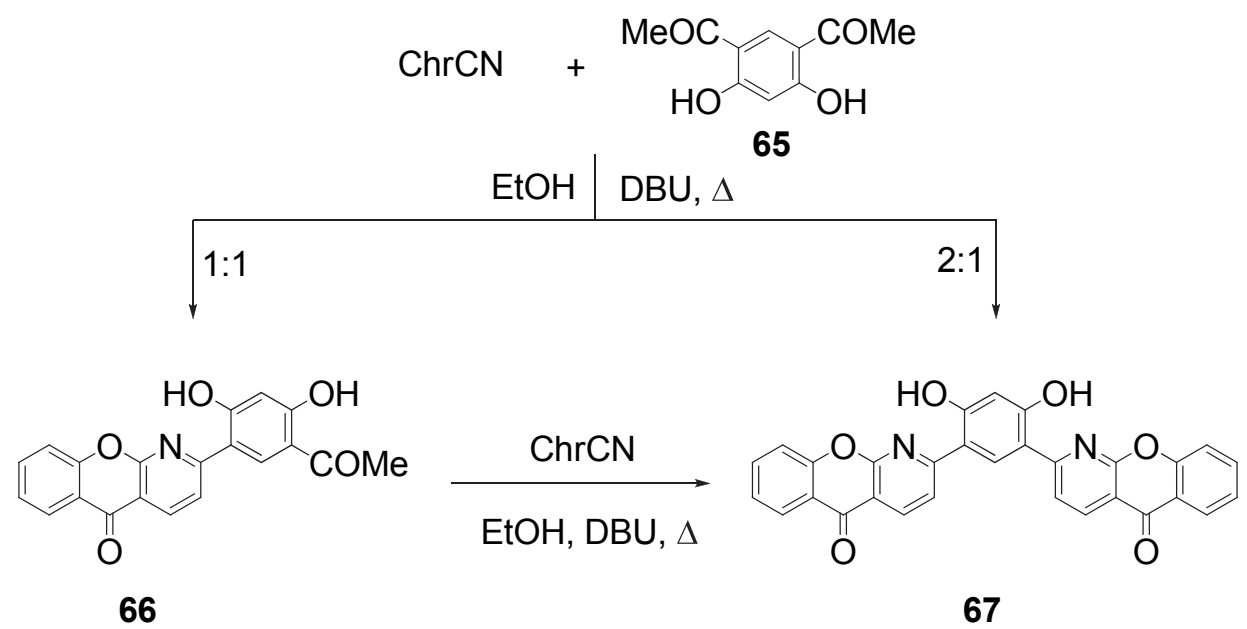

\section{Scheme 10}

\subsection{Reaction with active methylene compounds}

The title reaction reported since 2005 is being surveyed here. Ibrahim and his group ${ }^{31-34}$ have extensively studied the reaction of the cyanochromone $\mathbf{1}$ with various acyclic and cyclic methylene compounds. Thus, the nitrile 1 reacts with active methylene compounds as 68 ( $\mathrm{R}=$ $\left.\mathrm{Ph}, \mathrm{PhCO}, \mathrm{CO}_{2} \mathrm{Et}\right), 69$ and 70 ( $\left.\mathrm{R}=\mathrm{Ph}, \mathrm{PhS}, \mathrm{CO}_{2} \mathrm{Me}, \mathrm{CO}_{2} \mathrm{Et}, \mathrm{CONH}-\mathrm{N}=\mathrm{CHC}_{6} \mathrm{H}_{4} \mathrm{Cl}-4\right)$ in EtOHDBU giving the azaxanthones 71-73, respectively. ${ }^{31}$ Several cyclic $\alpha$-methylene ketones undergo smooth and efficient ring opening and ring closure (RORC) reaction with ChrCN yielding heteroannulated chromene systems. Thus, cyclopentanone, dimedone, thiazolone 74, pyrazolidin-3,5-dione $\mathbf{7 5}$ and barbituric(or thiobarbuturic) acid $\mathbf{7 6}$ give with ChrCN the tetracyclic compounds $\mathbf{7 7 - 8 1}$, respectively. ${ }^{31}$

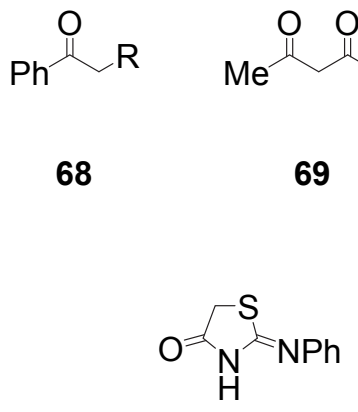

74
$\widehat{\mathrm{R}} \widehat{\mathrm{CN}}$

70

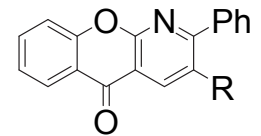

71

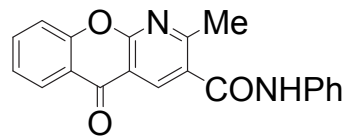

72

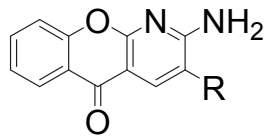

73<smiles>CC1(C)CC(=O)c2cc3c(=O)c4ccccc4oc3nc2C1</smiles>

78

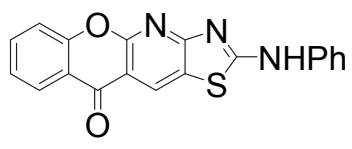

79

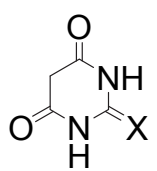

$76 X=0$ or $S$

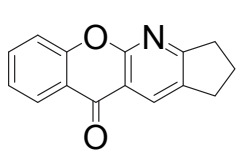

77

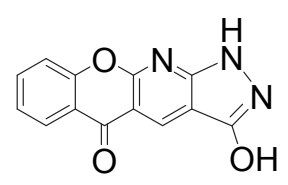

80

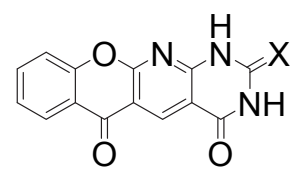

$81 X=0$ or $S$ 
8-Allyl-3-cyanochromone $\mathbf{8 2}$ behaves similarly as the unsubstituted 3-cyanochromone $\mathbf{1}$ towards several active methylene compounds. Thus, the nitrile $\mathbf{8 2}$ gives with malononitrile, phenylthioacetonitrile, cyanoacetamide, ethyl cyanoacetate, ethyl acetoacetate and ethyl benzoyl acetate in ethanol-DBU the 4-azaxanthone 83a-f, respectively. ${ }^{32}$ Reaction between $\mathbf{8 2}$ and barbituric acid under the same conditions affords the benzopyrano-fused heterocycle $84 .{ }^{32}$ The nitrile $\mathbf{1}$ as well as the aldehyde $\mathbf{2}$ when heated with the $\beta$-ketoacid $\mathbf{8 5}$ in DMF containing a few drops of piperidine gives the pyranoquinoline $\mathbf{8 6}$ instead of any azaxanthone. Here the conversion of $\mathbf{1}$ with the acid $\mathbf{8 5}$ involves a tandem Michael - retro-Michael - cyclization involving phenolic $\mathrm{OH}$ and $\mathrm{CN}$ functionalities and lactonization of the intermediate. ${ }^{33}$ The nitrile $\mathbf{8 2}$ similarly gives with $\mathbf{8 5}$ a product analogous to $\mathbf{8 6}$.

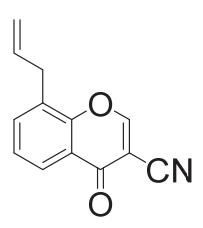

82

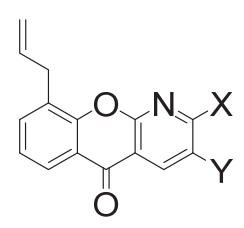

83

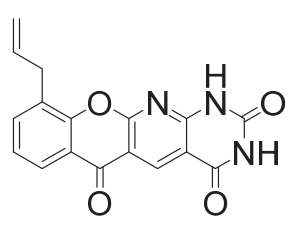

84

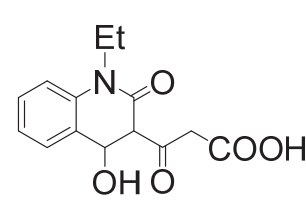

85

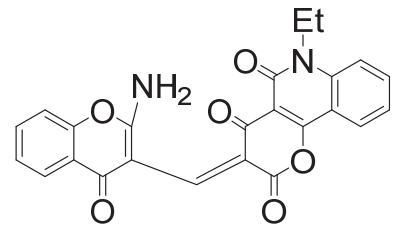

86

$\begin{array}{rll} & \mathrm{X} & \mathrm{Y} \\ \mathbf{8 3} \mathbf{a} & \mathrm{NH}_{2} & \mathrm{CN} \\ \mathbf{b} & \mathrm{NH}_{2} & \mathrm{SPh} \\ \mathbf{c} & \mathrm{NH}_{2} & \mathrm{CONH}_{2} \\ \mathbf{d} & \mathrm{NH}_{2} & \mathrm{CO}_{2} \mathrm{Et} \\ \mathbf{e} & \mathrm{Me} & \mathrm{CO}_{2} \mathrm{Et} \\ \mathbf{f} & \mathrm{Ph} & \mathrm{CO}_{2} \mathrm{Et}\end{array}$

Under basic condition ( $\mathrm{EtOH}, \mathrm{NEt}_{3}$ ), benzimidazole-2-acetonitrile 87 gives the pentacyclic compound 91 with 3-cyanochromone 1a but the azaxanthone 93b with 3-cyano-6methylchromone 1b (Scheme 11). ${ }^{34}$ Here the carbanion generated from the acetonitrile 87 undergoes Michael - retro-Michael to give the intermediate 88. Nucleophilicity of phenolic $\mathrm{OH}$ in $\mathbf{8 8}(\mathrm{R}=\mathrm{H})$ is less than that of its imidazole $\mathrm{NH}$; so its first cyclization $(\rightarrow \mathbf{9 0})$ involving $\mathrm{NH}$ and $\mathrm{CN}$ followed by a second one involving the phenolic $\mathrm{OH}$ and imine functionalities leads to the formation of the fused heterocycle 91 (path $a$ ). The intermediate $88(\mathrm{R}=\mathrm{Me}$ ) follows a different reaction course. Here the electron donating methyl group enhances the nucleophilicity of the phenolic $\mathrm{OH}$ of $\mathbf{8 8}$; so a process of double cyclization of $\mathbf{8 9}(\equiv \mathbf{8 8})$ initiated by its phenolic $\mathrm{OH}$ leads to 92 that by a 1,3-Hydrogen shift ultimately gives the imidazol-2-ylazaxanthone $\mathbf{9 3 \mathbf { b }}$ (path $b$ ). The chromone-aldehyde 2 and its 6-methyl homologue, however, behave similarly towards the nitrile 87 in giving $93 \mathbf{a}$ and $93 \mathbf{b}$, respectively. ${ }^{34}$ 


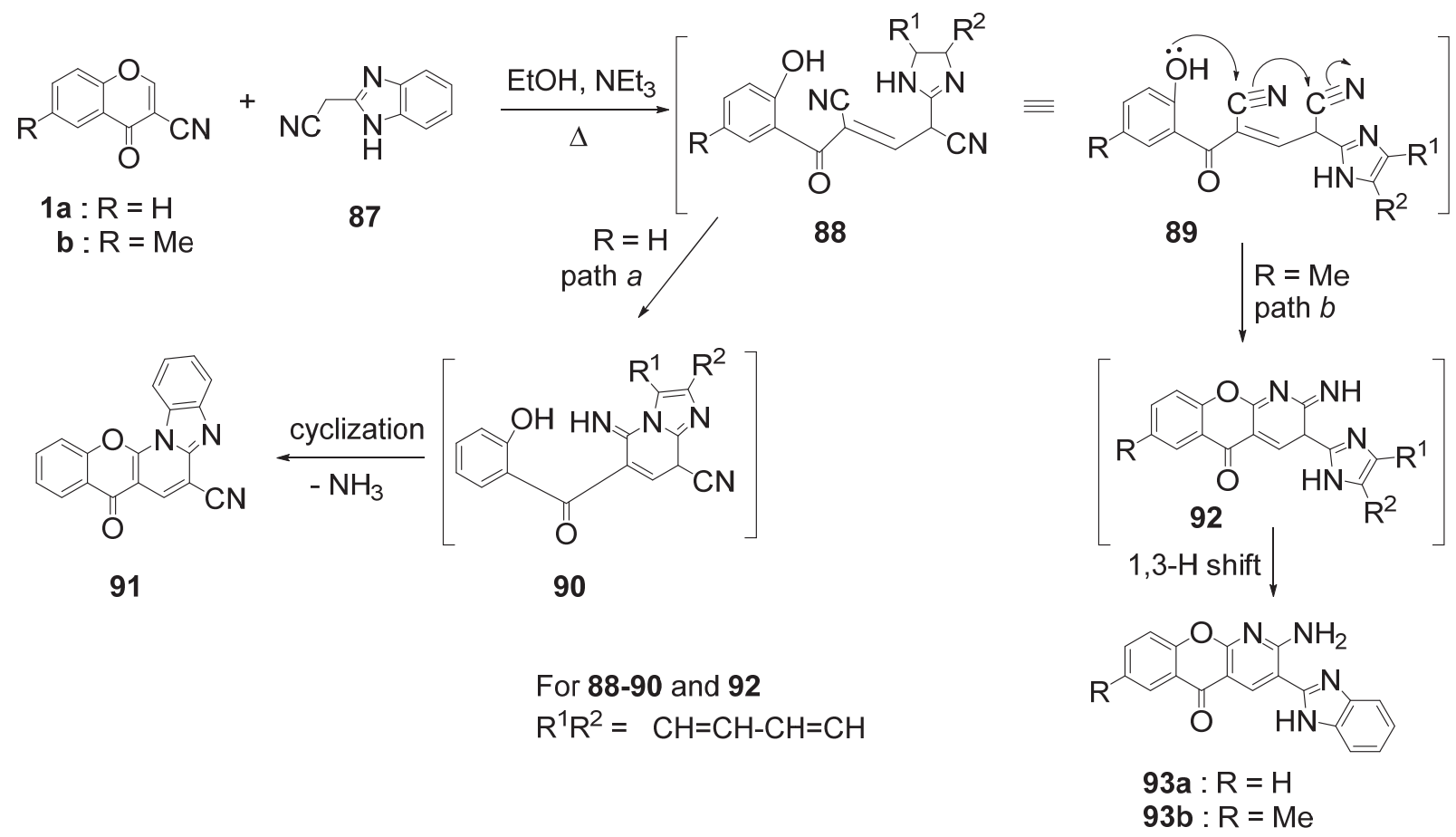

\section{Scheme 11}

The cyanochromone 1 is reported to give the pyrido-oxazole 96 when refluxed along with aceturic acid 94 in $\mathrm{Ac}_{2} \mathrm{O}$ containing fused $\mathrm{AcONa}^{16}$ but the chromenopyridine 98 with hippuric acid 95 presumably under identical conditions. ${ }^{35}$ Abdel-Rahman et al ${ }^{36}$ have, however, claimed to get 96 and 97 by heating 1 in $\mathrm{Ac}_{2} \mathrm{O}-\mathrm{AcONa}$ with aceturic acid and hippuric acid, respectively. Later Ibrahim $^{31}$ claimed that the reaction of 1 with hippuric acid 95 in $\mathrm{Ac}_{2} \mathrm{O}$ gave 99 but 97 in $\mathrm{Ac}_{2} \mathrm{O}$ in the presence of freshly fused AcONa. Now it seems that sodium acetate used for the preparation of 98 was not freshly fused. ${ }^{35}$ The product proposed to have the structure 98 or 99 has identical analytical and spectral (IR, NMR) data. An IR peak at $\sim 1735 \mathrm{~cm}^{-1}$ definitely points to the presence of an ester carbonyl group in the compound. Furthermore, $N$-acylation of an aromatic acid anilide as $\mathrm{PhNHCOPh}$ by $\mathrm{Ac}_{2} \mathrm{O}-\mathrm{AcONa}$ has not been realized though $\mathrm{Ac}_{2} \mathrm{O}-\mathrm{NaH}$ can bring about the said acylation. So the structure 98, not 99, should be attributed to the compound resulting from 1 and hippuric acid in refluxing acetic anhydride.

$\mathrm{RCONHCH} \mathrm{H}_{2} \mathrm{COOH}$

$94: \mathrm{R}=\mathrm{Me}$

$95: \mathrm{R}=\mathrm{Ph}$

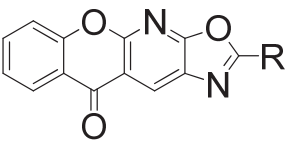

$96: \mathrm{R}=\mathrm{Me}$

$97: \mathrm{R}=\mathrm{Ph}$

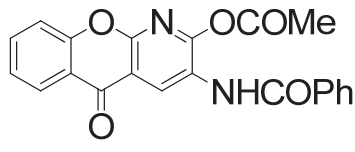

98<smiles>CC(=O)N(C(=O)c1ccccc1)c1cc2c(=O)c3ccccc3oc2[nH]c1=O</smiles>

99 
A recent report ${ }^{37}$ for the synthesis of ethyl azaxanthone-2-carboxylate $\mathbf{1 0 1}$ by reacting the nitrile 1 with a $\beta$-keto ester $\mathbf{1 0 0}$ (Scheme 12) claims that yield of azaxanthone $\mathbf{1 0 1}$ is higher when the reaction is conducted under ultrasonication than that obtained by conventional heating.

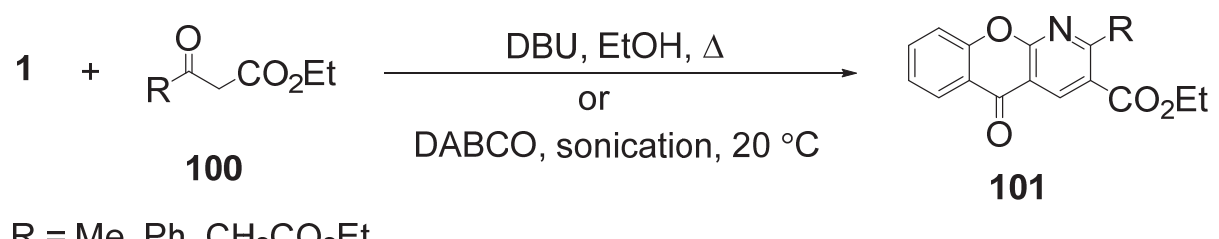

\section{Scheme 12}

\subsection{Reaction with enamines}

The carbamimidoylacetic acid ester $\mathbf{1 0 2}$ in an aqueous medium containing $\mathrm{NaOAc}$ functions as an enediamine to undergo Michael - retro-Michael reaction; the resultant intermediate $\mathbf{1 0 3}$ by double cyclization, the first one involving phenolic $\mathrm{OH}$ and $\mathrm{CN}$ groups and the second one involving $\mathrm{NH}_{2}$ and $\mathrm{CO}$ groups, to $\mathbf{1 0 4}$ and subsequent hydrolysis gives the coumarinopyridine 105 (Scheme 13). ${ }^{38}$

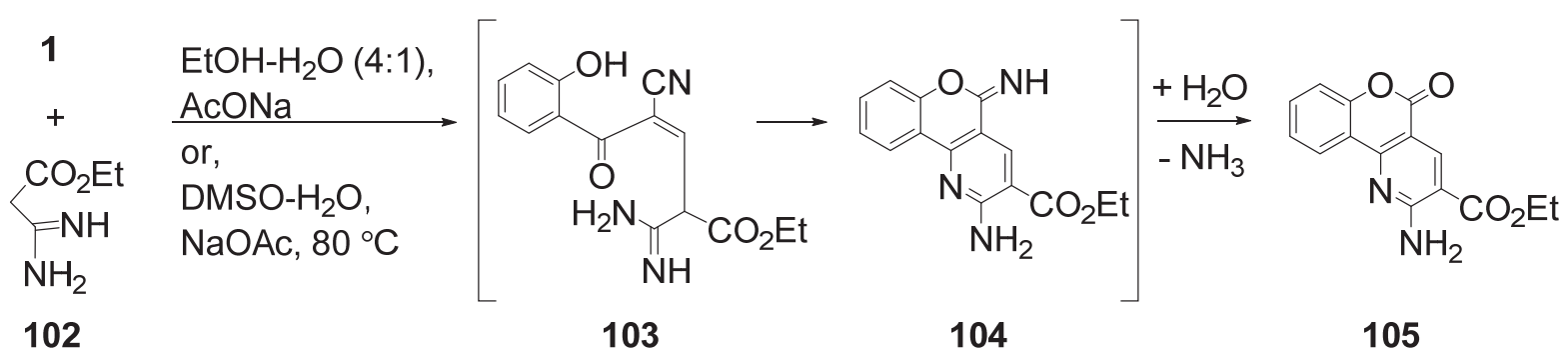

\section{Scheme 13}

Heating a mixture of the naphthopyran-3-nitrile 106 or its 'chemical equivalent' 2-amino3-formylnaphthopyran-4-one 107 with the enamine $108(\mathrm{X}=\mathrm{Me}, \mathrm{OEt})$ in $\mathrm{DMF}$ at $80^{\circ} \mathrm{C}$ affords the azaxanthone 109. A similar reaction of 106 with 6-amino-1,3-dimethyluracil 110 gives the pyridopyrimidine 111. ${ }^{39}$ 


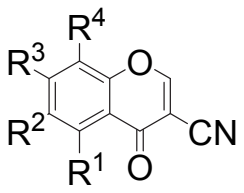

106<smiles></smiles>

109<smiles></smiles>

107<smiles>[X]C(C)=CC(N)=O</smiles>

108

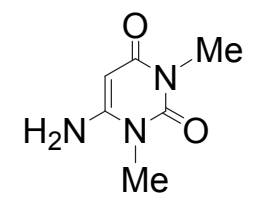

110

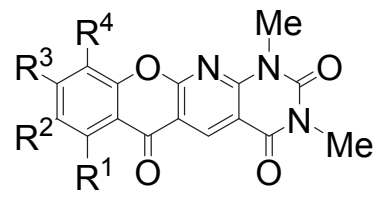

111

For 106, 107, 109 and 111:

$\mathrm{R}^{1}, \mathrm{R}^{2}=\mathrm{H}, \mathrm{R}^{3} \mathrm{R}^{4}=\mathrm{CH}=\mathrm{CH}-\mathrm{CH}=\mathrm{CH} ; \mathrm{R}^{1} \mathrm{R}^{2}=\mathrm{CH}=\mathrm{CH}-\mathrm{CH}=\mathrm{CH}, \mathrm{R}^{3}, \mathrm{R}^{4}=\mathrm{H}$

\subsection{Reaction with pyridinium phenacylide}

Pyridinium phenacylide 112 undergoes [3+2]dipolar cycloaddition with the pyran-2,3-olefinic bond of $\mathrm{ChrCHO}$ as well as $\mathrm{ChrCOOH}$; the resultant cycloadduct by base catalyzed deformylative or decarboxylative pyran ring opening and subsequent air oxidation gives the indolozine 113. In contrast, the phenacylide 112 with $\mathrm{ChrCN}$ gives the 1-azirine 114, its formation involving 1,2-addition of phenacylide carbanion to $-\mathrm{C} \equiv \mathrm{N}$ of $\mathbf{1}$ followed by cyclization and a 1,3-hydrogen shift. ${ }^{40} \mathrm{Kornev}$ et $a l^{41}$ unfortunately failed to get the 1-azirine 114; they claimed to have got the ylid $\mathbf{1 1 5}$ by refluxing a mixture of $\mathrm{ChCN}$, phenacylpyridinium bromide and potassium carbonate (in 1:1:1 or 2 equivalent) in acetone. Here the phenacylide 112 also functions as a nucleophile to undergo Michael addition to the $\alpha, \beta$-unsaturated nitrile functionality of 1 with concomitant opening of the pyran ring. We contend that this product proposed to be the ylid 115 should exist as the dipolar ion 116.

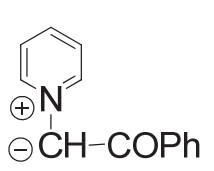

112

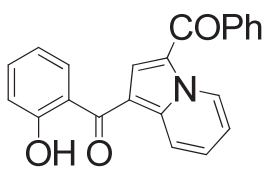

113

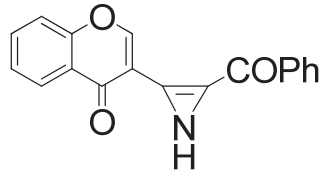

114

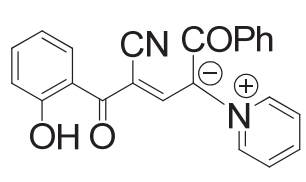

115

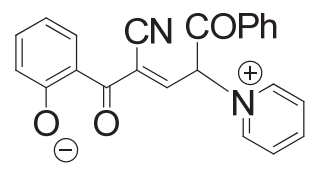

116

\subsection{Reaction with 1,3-bis-silyl ethers of 1,3-dicarbonyl compounds}

Reaction of 3-cyanochromone 1 with 1,3-bis-silyl enolates of general formula 118 as the synthetic equivalent of 1,3-dicarbonyl compounds in the presence of trimethylsilyl triflate (TMSOTf) has been extensively investigated by Langer et al. ${ }^{42-49}$ Here the terminal carbon of the butadiene 118 is captured by the 1-benzopyrilium triflate 117, generated from 1 and TMSOTf; the resultant adduct 119 (a diastereoisomeric mixture) by a base catalyzed retro-Michael gives 
the acrylonitrile 120 that undergoes a two-step cyclization to the azaxanthone 121 (Scheme 14 path $a)$. An alternative mode of cyclization of $120\left(\mathrm{R}^{2}=\mathrm{H}, \mathrm{R}^{3}=\mathrm{OMe}, \mathrm{OEt}\right)$ by an aldollactonization mechanism to the biaryllactone $\mathbf{1 2 2}$ is also feasible (path $b$ ). Yields of the two types of compounds resulting from 1 and some selected members of $\mathbf{1 1 8}$ are given in Table 1.

Table 1. Yields (\%) of the compounds 121 and 122 from the reaction of some bis-silyl ethers 118 with $\mathrm{ChrCN}$

\begin{tabular}{ccccccc}
\hline \multirow{2}{*}{ S1 No. } & \multicolumn{3}{c}{ Silyl ethers 118 } & Azaxanthone & Benzocoumarin & Ref. \\
\cline { 2 - 4 } & $\mathrm{R}^{1}$ & $\mathrm{R}^{2}$ & $\mathrm{R}^{3}$ & $\mathbf{1 2 1}$ & $\mathbf{1 2 2}$ & \\
\hline 1 & $\mathrm{H}$ & $\mathrm{H}$ & $\mathrm{OMe}$ & 41 & - & 42,43 \\
2 & $\mathrm{Me}$ & $\mathrm{H}$ & $\mathrm{OMe}$ & 52 & - & 42,43 \\
3 & $\mathrm{Et}$ & $\mathrm{H}$ & $\mathrm{OEt}$ & 54 & 13 & 42,43 \\
4 & $\mathrm{OMe}$ & $\mathrm{H}$ & $\mathrm{OMe}$ & 47 & 11 & 42,43 \\
5 & $-\left(\mathrm{CH}_{2}\right)_{3}-$ & & $\mathrm{OEt}$ & 36 & - & 42,43 \\
6 & $4-\mathrm{MeC} \mathrm{H}_{4}$ & $\mathrm{H}$ & $\mathrm{OMe}$ & 63 & - & 44 \\
7 & $\mathrm{H}$ & $\mathrm{Cl}$ & $\mathrm{OEt}$ & 58 & - & 45 \\
8 & $\mathrm{H}$ & $\mathrm{F}$ & $\mathrm{OEt}$ & 56 & - & 46 \\
9 & $n-\mathrm{Pr}$ & $\mathrm{H}$ & $\mathrm{OEt}$ & - & 37 & 47 \\
10 & $n-\mathrm{Bu}$ & $\mathrm{H}$ & $\mathrm{OEt}$ & - & 42 & 47 \\
\hline
\end{tabular}

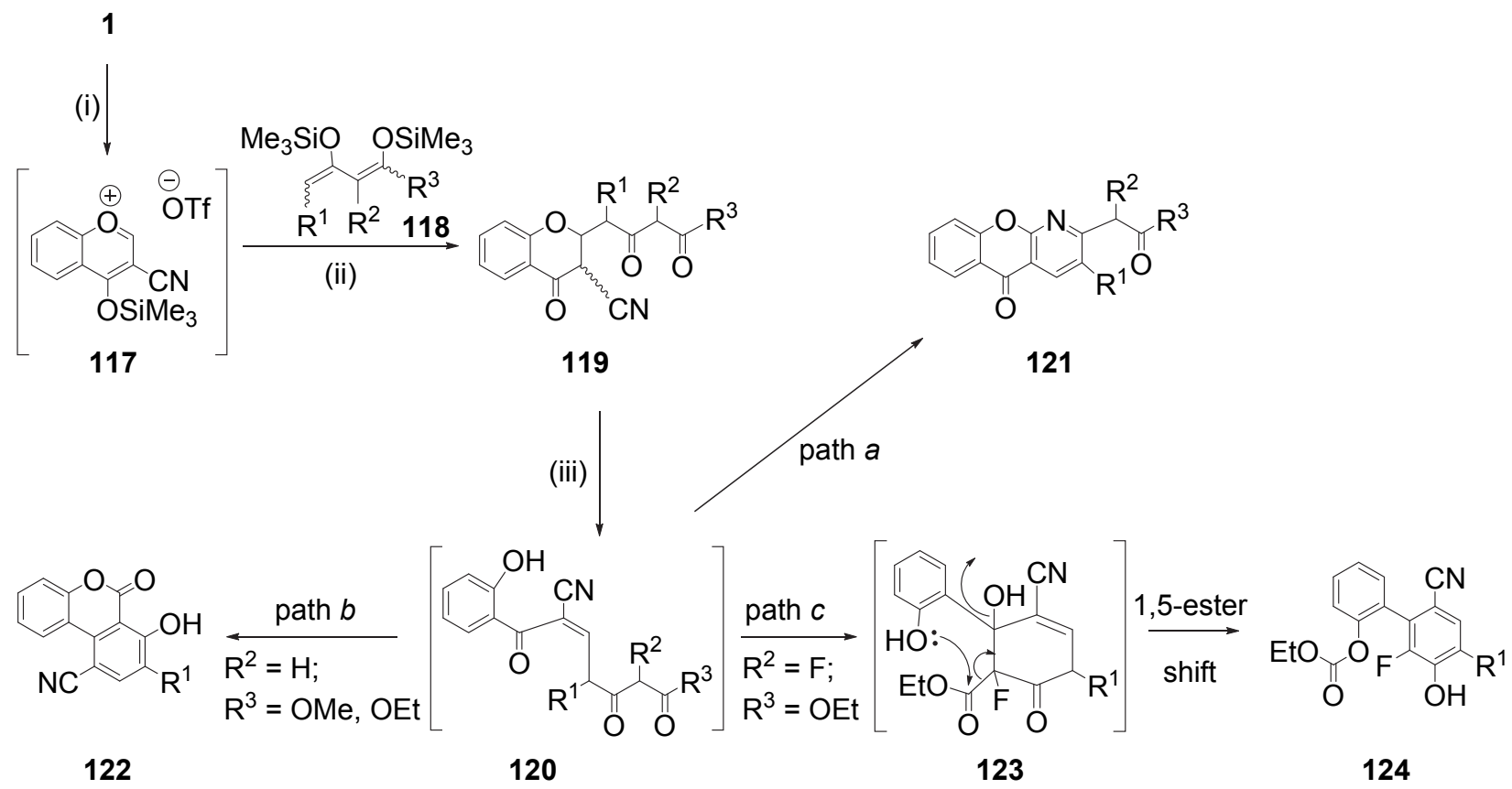

Scheme 14. Reagents and conditions: (i) TMSOTf, $\mathrm{CH}_{2} \mathrm{Cl}_{2}, 0{ }^{\circ} \mathrm{C}, 1 \mathrm{~h}$; (ii) $\mathrm{CH}_{2} \mathrm{Cl}_{2}, 2{ }^{\circ} \mathrm{C}, 12 \mathrm{~h}$, then $\mathrm{HCl}(10 \%)$; (iii) $\mathrm{NEt}_{3}, \mathrm{EtOH}, 20^{\circ} \mathrm{C}, 12 \mathrm{~h}$, then $\mathrm{HCl}(1 \mathrm{M})$. 
The enolate $118\left(\mathrm{R}^{1} \mathrm{R}^{2}=\left(\mathrm{CH}_{2}\right)_{4},\left(\mathrm{CH}_{2}\right)_{9} ; \mathrm{R}^{3}=\mathrm{OMe}\right)$ as well as $118\left(\mathrm{R}^{1}=\mathrm{R}^{2}=\mathrm{H} ; \mathrm{R}^{3}=\right.$ $\mathrm{Me}$ or $\mathrm{Ph}$ ) i.e. the bis-silyl ether prepared from acetyl(or benzoyl)acetone fails to react with $\mathrm{ChrCN}^{48}$ Interestingly, the reaction of 1 with 4-alkyl-2-fluorobutadiene $118\left(\mathrm{R}^{1}=\mathrm{Me}, n-\operatorname{Pr}, n\right.$ $\mathrm{Bu}, n$-pent, $n$-hex, $n$-oct; $\mathrm{R}^{2}=\mathrm{F} ; \mathrm{R}^{3}=\mathrm{OEt}$ ) results in the biaryl 124 in $\sim 70 \%$ yield accompanied by no or a little $(0-20 \%)$ of azaxanthone 121; here the major product 124 arises by cyclization of the intermediate $\mathbf{1 2 0}$ to $\mathbf{1 2 3}$ and a subsequent 1,5-ester shift (Scheme 14 - path c). ${ }^{49}$ Karapetyan $^{50}$ could isolate only the azaxanthone $121\left(\mathrm{R}^{1}=n\right.$-oct; $\left.\mathrm{R}^{2}=\mathrm{H} ; \mathrm{R}^{3}=\mathrm{OEt}\right)$ in $28 \%$ yield from the reaction mixture of 1 and $\mathbf{1 1 8}\left(\mathrm{R}^{1}=n\right.$-Oct; $\left.\mathrm{R}^{2}=\mathrm{H}, \mathrm{R}^{3}=\mathrm{OEt}\right)$.

\section{Aza- and Oxa- Michael - Allylation}

Allyl carbamate 125 undergoes palladium catalyzed decarboxylative and regioselective azaMichael - allylation across the pyran 2,3- $\pi$ bond of $\mathrm{ChrCN}$ to give the chromanone 126 in one diastereoisomeric form (Scheme 15). ${ }^{51}$ This chromanone 126 cannot be prepared by $\operatorname{Pd}(0)$ catalyzed three component coupling reaction between $\mathrm{ChrCN}, \mathrm{RNHR}^{1}$ and allyl acetate.

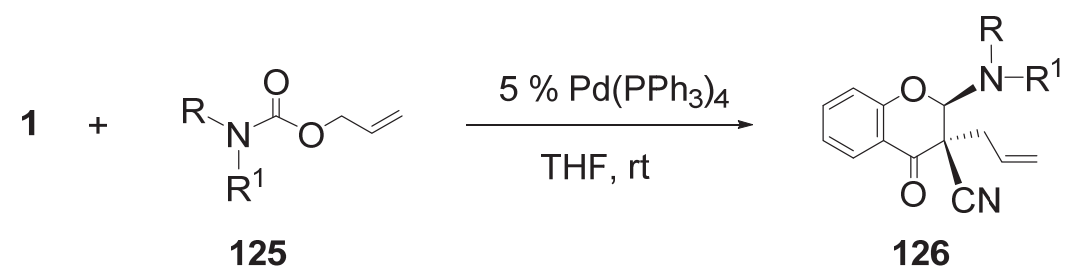

For 125 and $126: \mathrm{R}=\mathrm{Me}, \mathrm{Ph}, 4-\mathrm{Me}-\mathrm{C}_{6} \mathrm{H}_{4}, 4-\mathrm{MeO}-\mathrm{C}_{6} \mathrm{H}_{4}$, $\mathrm{R}^{1}=\mathrm{CO}_{2} \mathrm{Et}, \mathrm{COCH}=\mathrm{CH}_{2}$

\section{Scheme 15}

Allyl carbonate 127 likewise the carbamate 125 reacts with $\mathrm{ChrCN}$ in the presence of the electron rich tetrabutylammonium ferrate $\mathrm{Bu}_{4} \mathrm{~N}\left[\mathrm{Fe}(\mathrm{CO})_{3} \mathrm{NO}\right]$ (TBAFe) and an $N_{,} N^{\prime}-$ diphenyldihydrobenzimidazole derived carbene ligand $\mathbf{L}$ to give the 2-methoxychromanone 128 in $79 \%$ yield, the ratio of this diastereoisomer over the other one being $>20: 1$ (Scheme 16). ${ }^{52}$

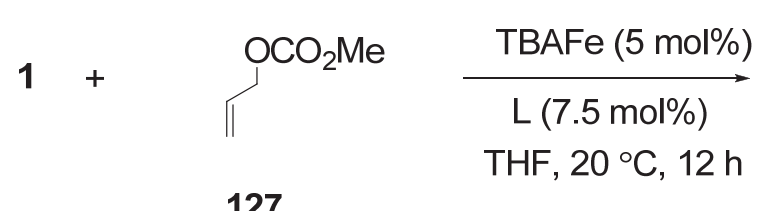

127

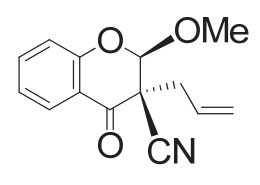

128

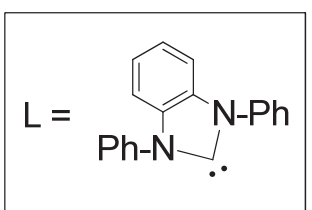

\section{Scheme 16}

The reaction of chiral secondary allyl carbonate 129 with $\mathrm{ChrCN}$ under the aforesaid conditions results in the regioselective formation of the ipso-substitution product $\mathbf{1 3 0}$ albeit as a 1:1 mixture of the diastereoisomers. ${ }^{52}$ Fe-catalyzed three component coupling of ChrCN, allyl acetate and an external alcohol is possible (vide section 9). 


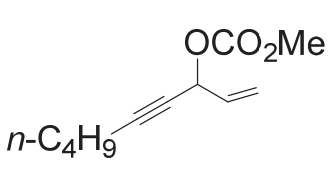

129

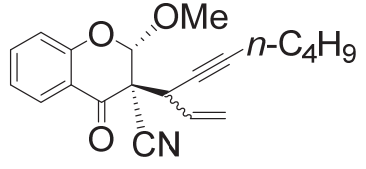

130

\section{Cycloaddition Reactions}

\section{1. $[3+2]$ Dipolar cycloaddition}

2,3-Olefinic bond of $\mathbf{1}$ participates in cycloaddition reaction with several 1,3-dipoles. Its reaction with several diazoalkanes ultimately leading to 2-alkyl-3-cyanochromone has been reviewed. ${ }^{1} \mathrm{~A}$ diarylnitrilmine exists as 1,3-dipolar species 131A and 131B; their [3+2] cycloaddition with ChrCN forms the adducts 132 and $\mathbf{1 3 3}$ which by a retro-Diels-Alder process gives respectively 4- and 5-cyanopyrazole 134 and 135 along with the ketoketene 136 that takes up water forming salicylic acid 137 (Scheme 17). ${ }^{53}$

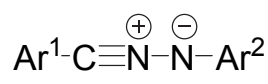

$131 \mathrm{~A}$

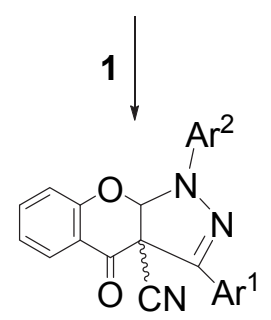

132

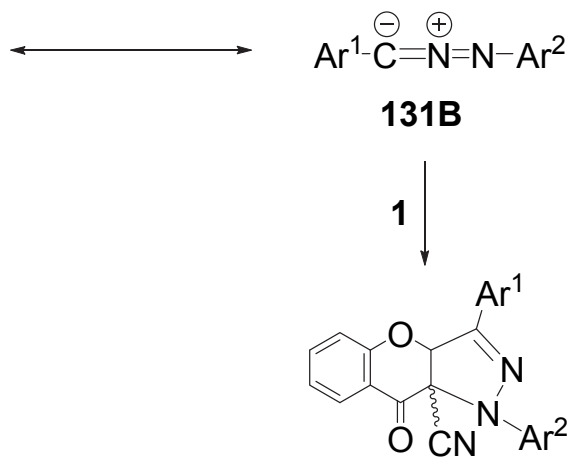

133

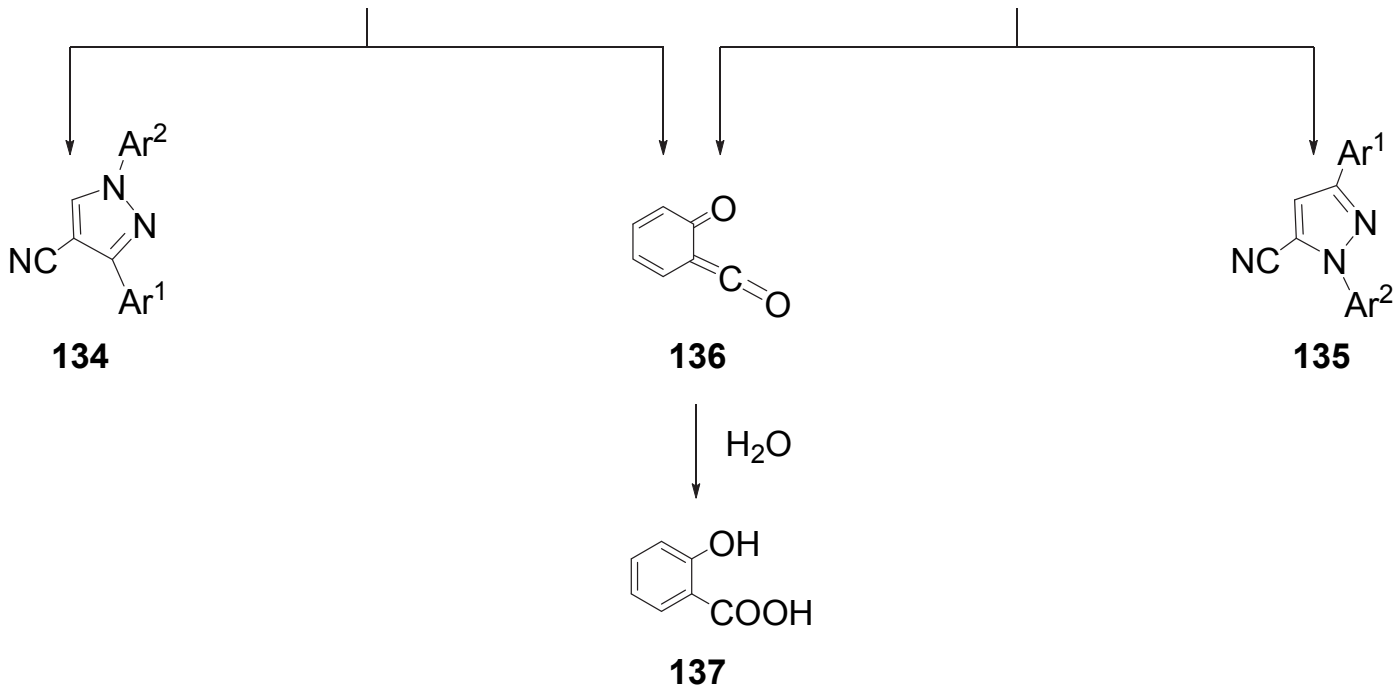

Scheme 17 
$N$-Tosyl-5,5-divinyloxazolidin-5-one $138\left(\mathrm{R}=\mathrm{CH}=\mathrm{CH}_{2}\right)$, prepared by sequential treatment of methyl $N$-Boc-glycinate with vinylmagnesium bromide, potassium $t$-butoxide and tosyl chloride, undergoes palladium catalyzed decarboxylative cyclization across the pyran-2,3double bond of ChrCN to give the pyrrolo[2,3-b][1]benzopyran derivative 140 (Scheme 18). ${ }^{54}$ Here $\operatorname{Pd}(0)$ catalyst brings about decarboxylation of the oxazolidinone 138 to the 1,3-dipole 139 that undergoes stereoselective [3+2] dipolar cycloaddition to the $\alpha, \beta$-unsaturated nitrile 1 giving the adduct 140.<smiles>[R]C1([R])CN([As])C(=O)O1</smiles>

138

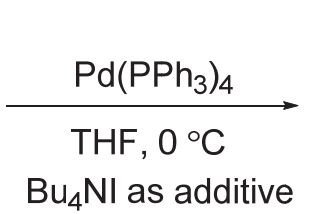

$\mathrm{Bu}_{4} \mathrm{NI}$ as additive

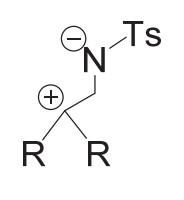

139

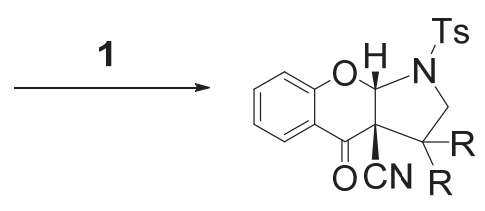

140

\section{Scheme 18}<smiles></smiles>

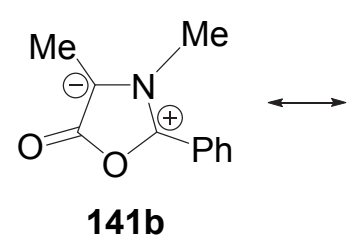<smiles></smiles><smiles>CC1C(=O)O[14C](C)N1c1ccccc1</smiles><smiles>Ic1cccnc1</smiles>

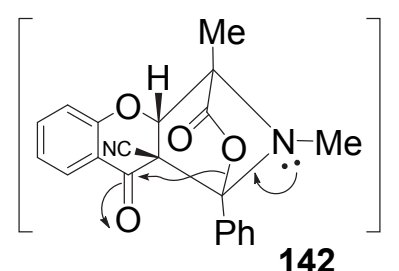<smiles>CCCC1CCCCC1</smiles>

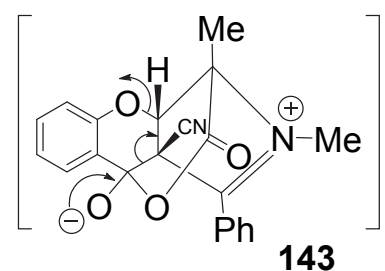

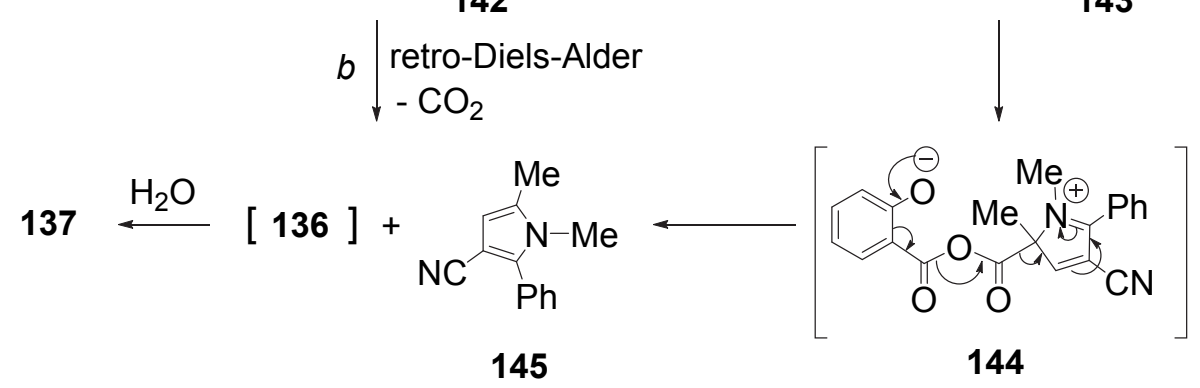
143

\section{Scheme 19}

The 1,3-dipolar cycloaddition of 3,4-dimethyl-2-phenyloxazolium-5-olate (münchone) 141a to $\mathrm{ChrCN}$ is reported by Cordaro et $a l^{55}$ to afford the pyrrole 145 together with salicylic acid by a mechanism as depicted in Scheme 19 - path $a$. Of all the resonating structures (141a-d) 
of the said münchone, the predominating 1,3-dipolar species 141b forms with ChrCN the endoadduct 142 that undergoes subsequent decarboxylative degradation to give the products via the intermediates 143 and 144 . We feel that the formation of the pyrrole 145 and salicylic acid from 142 through a retro-Diels-Alder process and subsequent decarboxylation (path $b$ ) is also plausible.

The azomethine ylid 146, derived from sarcosine and paraformaldehyde, also undergoes diastereoselective [3+2] cycloaddition with $\mathrm{ChrCN}$ in refluxing benzene giving the adduct 147 accompanied by a small amount of 148 arising from a second [3+2] dipolar cycloaddition of the ylid 146 to the carbonyl group of 147 (Scheme 20). ${ }^{56}$ The compound 148 is obtained as a single diastereoisomer when $\mathrm{ChrCN}$ is reacted with excess sarcosine (6 equiv) and paraformaldehyde (10 equiv) and it on heating in $\mathrm{HCl}$ transforms into the tetracycle 149 through a sequence of opening of the semi-aminal methylene group, deformylation and intramolecular 1,2-addition of $\mathrm{MeNH}$ to $\mathrm{CN}$ group.

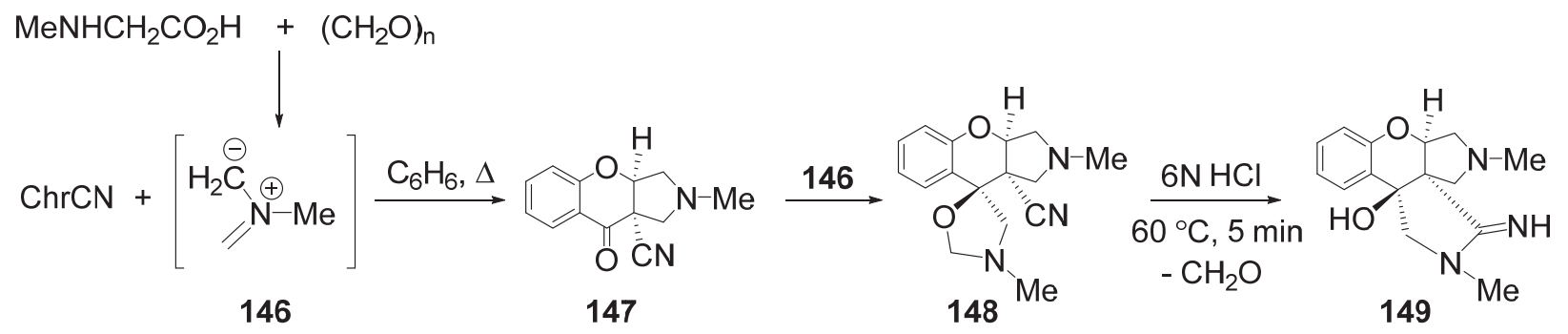

Scheme 20

Reaction of ChrCN with a few 1,3-dipolar species generated from isocyanide and acetylenic ester is described in section 9.

\section{2. $[4+2]$ Cycloaddition}

Diels-Alder reaction of the unsaturated nitrile 1 with several oxygenated and non-oxygenated dienes extensively studied by Hsung et $a l^{57-60}$ has already been reviewed. ${ }^{1}$ A mixture of ChrCN and cyclohexadiene when heated under reflux in $o$-dichlorobenzene forms the endo-adduct 150, no catalyst being required. ${ }^{61,62}$ This adduct on UV irradiation undergoes intramolecular [2+2] alkene-arene photocyclization to $\mathbf{1 5 1}$. The diene system in $\mathbf{1 5 1}$ can capture in situ generated phenyl vinyl ketone yielding the D-A adduct 152; the latter (152) on UV irradiation in benzene triggers an intramolecular Paterno-Büchi reaction to give the oxetane 153 (Scheme 21). The conversion $(\mathbf{1} \rightarrow \mathbf{1 5 3})$ involves a double-tandem [4+2].[2+2].[4+2].[2+2] cycloaddition process. The nature of the products resulting from the protolytic metathesis of the polycycle $\mathbf{1 5 3}$ has also been reported. ${ }^{61,62}$ 


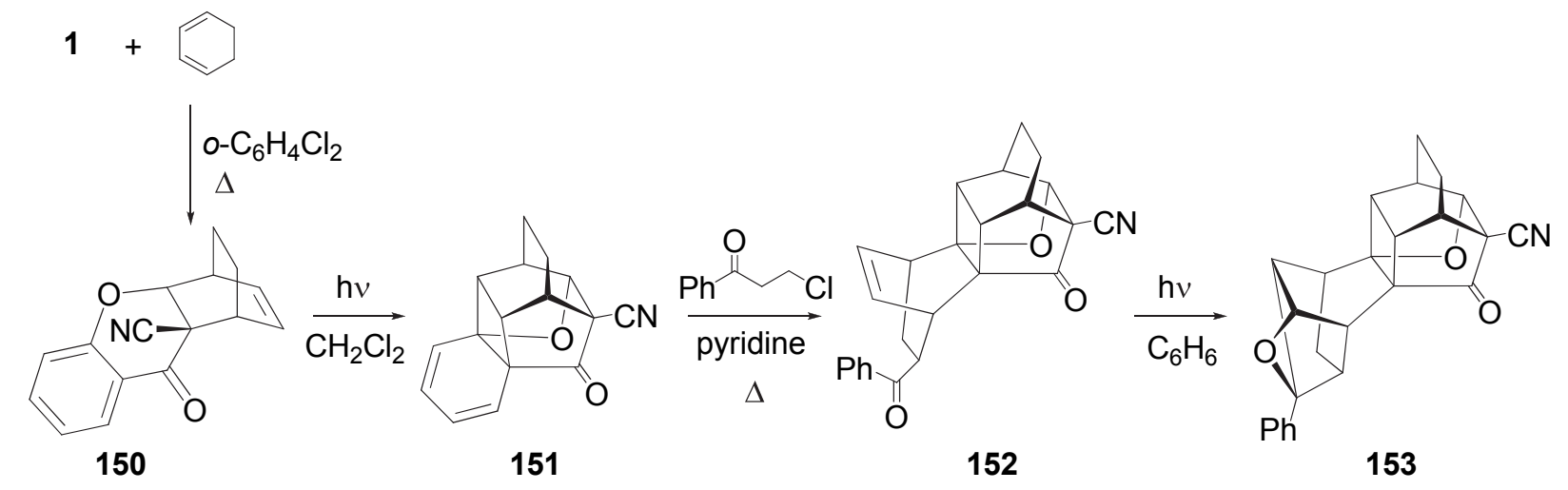

\section{Scheme 21}

The nitrile 1 undergoes [4+2] cycloaddition with 2,4-hexadienals 154a-f in the presence of squaramide-based organocatalyst 155 to give respectively tetrahydroxanthones 156a-f in more than 20:1 diastereoisomeric ratio and in approximately 90\% enantiomeric excess (Scheme 22). ${ }^{63}$

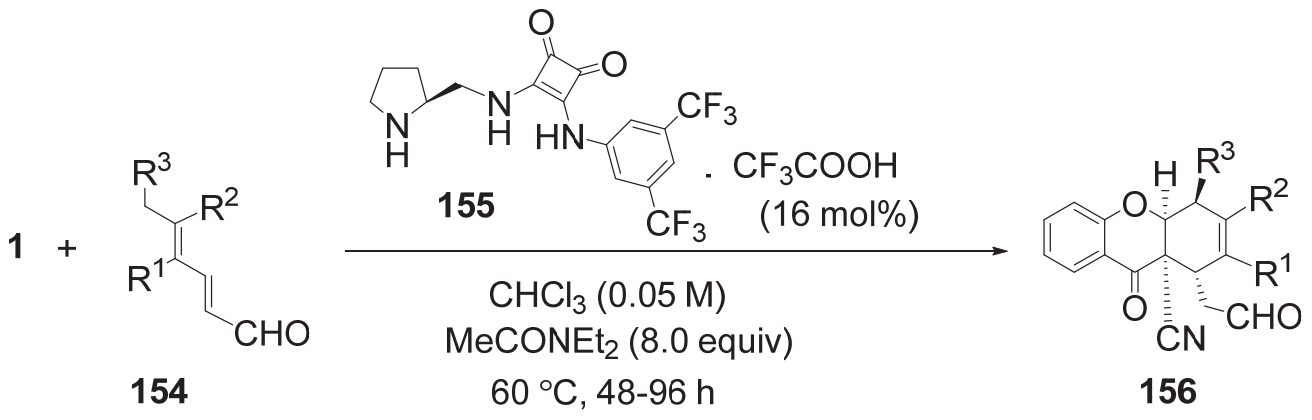

\section{Scheme 22}

$\begin{array}{rlll}\text { For 154 and 156 : } & \mathrm{R}^{1} & \mathrm{R}^{2} & \mathrm{R}^{3} \\ \text { a } & \mathrm{H} & \mathrm{H} & \mathrm{H} \\ \text { b } & \mathrm{H} & \mathrm{Me} & \mathrm{H} \\ \text { c } & \mathrm{Me} & \mathrm{H} & \mathrm{H} \\ \text { d } & \mathrm{Ph} & \mathrm{H} & \mathrm{H} \\ \text { e } & \mathrm{Ph} & \mathrm{H} & \mathrm{Me} \\ \text { f } & \mathrm{Me} & \mathrm{H} & \mathrm{Me}\end{array}$

The compound 156b has been subjected to various transformations. ${ }^{63}$ As for example, 156b by reduction with sodium borohydride gives 157 that on acid hydrolysis gives the lactone 158 in more than 20:1 d.r. The compound 156b on treatment with sodium triacetoxyborohydride followed by acid hydrolysis affords the fused pyranone 159 in >20:1 d.r. (Scheme 23). 


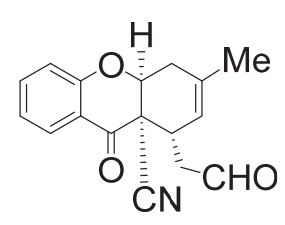

$156 b$

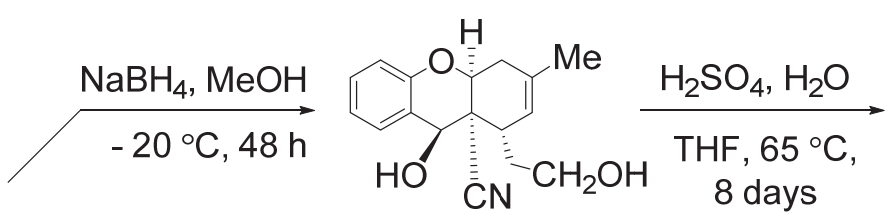

157

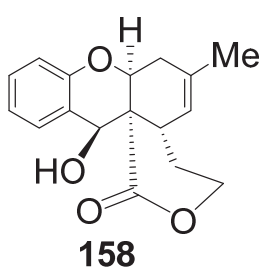

158

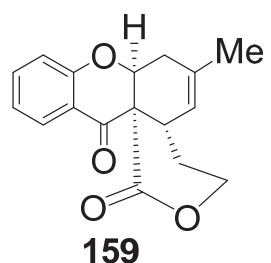

\section{Scheme 23}

\section{3-Cyanochromone as a Component in One-pot Multicomponent Synthesis}

The synthesis of the cyclohexanoxanthone $\mathbf{7 8}$ by heating a mixture of the nitrile $\mathbf{1}$, dimedone and ammonium acetate in ethanol under reflux has been regarded as a three-component synthesis. ${ }^{64}$ Here $\mathrm{ChrCN}$ is converted under basic conditions to 2-amino-3-formylchromone 2 that condenses with dimedone giving the expected product $\mathbf{7 8 .}$

A mixture of $\mathrm{ChrCN}$, benzaldehyde $160(\mathrm{R}=\mathrm{H}$, electron withdrawing or electron donating group) and $\mathrm{AcONH}_{4}$ in $\mathrm{DMF}$ solution containing $\mathrm{CuCl}_{2}$ at $100{ }^{\circ} \mathrm{C}$ affords 2,4diazaxanthone 164 (Scheme 24), its yield being increased to $85 \%$ when 1.2 equivalent of $\mathrm{CuCl}_{2}$ is present as an oxidant in the reaction mixture. ${ }^{65}$ It is assumed that the aldimine 161, generated in situ from the aldehyde $\mathbf{1 6 0}$ and $\mathrm{AcONH}_{4}$, serves as a nitrogen nucleophile in an efficient cascade aza-Michael - retro-Michael $(\rightarrow \mathbf{1 6 2})$ - cyclization $(\rightarrow \mathbf{1 6 3})$ - dehydrogenation $(\rightarrow \mathbf{1 6 4})$ reaction sequence. When benzaldehyde $\mathbf{1 6 0}$ is replaced by paraformaldehyde, the 3-unsubstituted diazaxanthone 164 ( $\mathrm{H}$ in place of $\left.\mathrm{C}_{6} \mathrm{H}_{4} \mathrm{R}\right)$ is obtained in $74 \%$ yield.
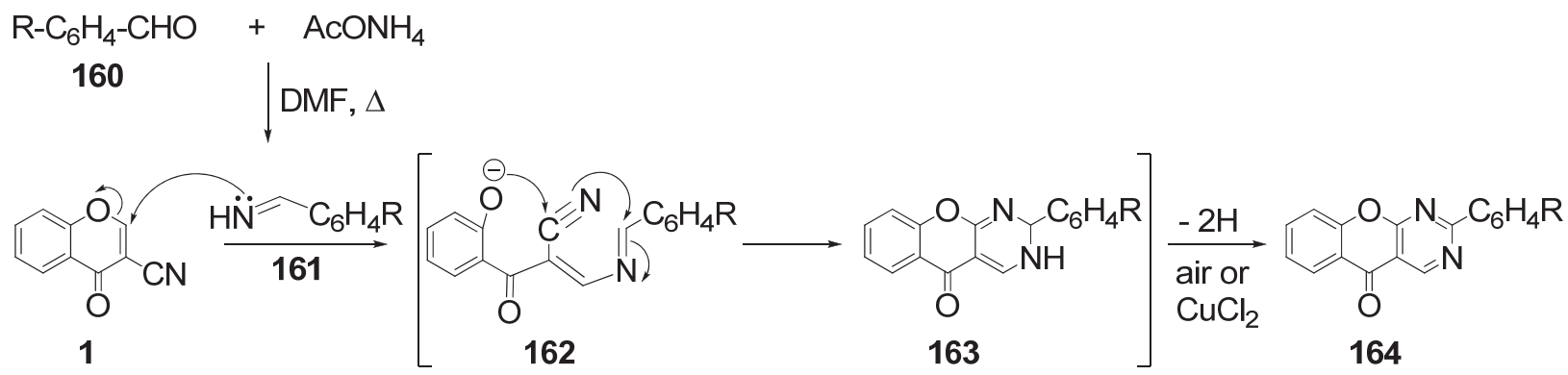

\section{Scheme 24}

Palladium catalyzed three-component coupling reaction between the nitrile $\mathbf{1}$, alcohol 165 and allyl acetate 166 leads to the highly substituted chromanone 167 (Scheme 25). ${ }^{66}$ The 
stereochemistry of the product $\mathbf{1 6 7}$ is given in comparison with similar amino - allylation of the unsaturated nitrile 1 with an allyl carbamate. ${ }^{51}$ It is to be noted that $t$-butanol does not participate in this (TCC) reaction and propargyl alcohol gives a complex mixture. An account of Pdcatalyzed alkoxy - allylation by an alcohol and allyl acetate and decarboxylative amino allylation by allyl carbamates across the pyran 2,3-double bond of the nitrile 1 with plausible mechanisms has been published. ${ }^{67}$

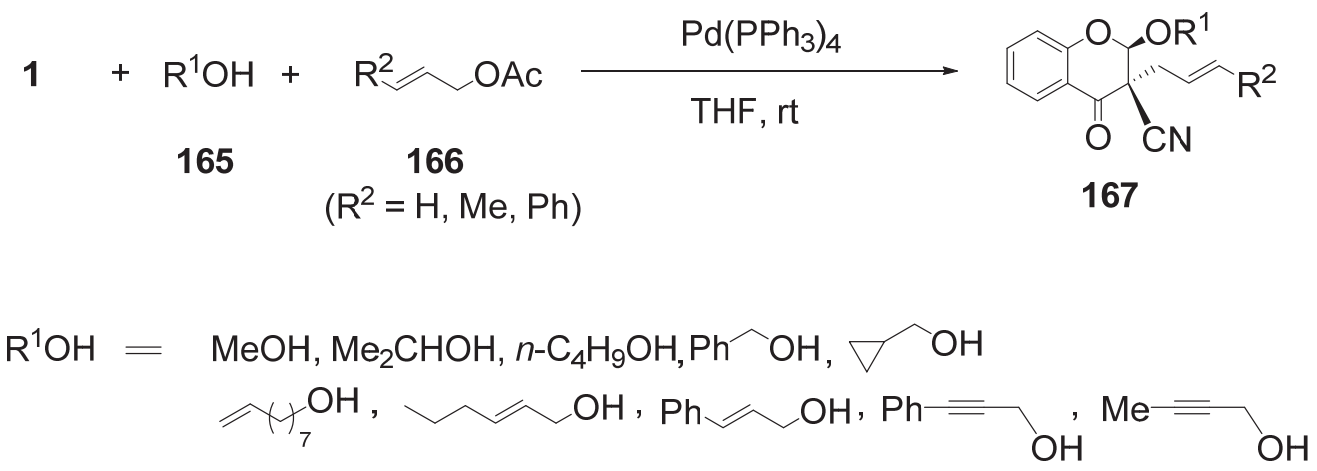

\section{Scheme 25}

The reaction between $\mathrm{ChrCN}$, acetylene carboxylate 168 and isocyanide 169 in a 1:1.2:1.2 molar ratio yields the spirobenzofuran $\mathbf{1 7 3}$ as the only product (Scheme 26). ${ }^{68}$ The 1,3 dipolar species 170, generated from acetylene carboxylate 168 and isonitrile 169, undergoes [3+2] dipolar cycloaddition (perhaps a two-step process - vide infra); the cycloadduct 171 rearranges under base catalysis to the spirocompound 173 via the intermediate 172, isonitrile 169 functioning as the base. The product $173\left(\mathrm{E}=\mathrm{CO}_{2} \mathrm{Me}\right.$ or $\left.\mathrm{CO}_{2} \mathrm{Et}\right)$ is obtained in $56-64 \%$ yield but $173\left(\mathrm{E}=\mathrm{H}, \mathrm{R}^{1}=\mathrm{Me}\right)$ in less than $20 \%$ yield.

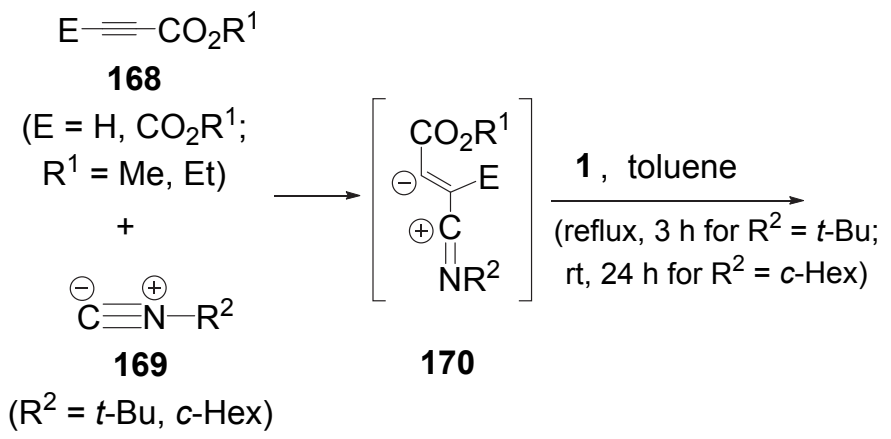

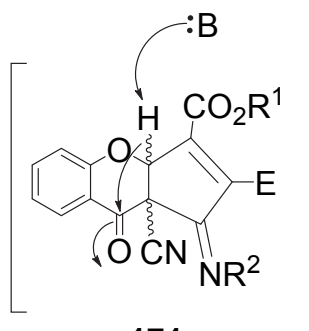

171

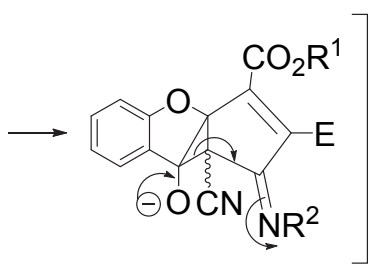

172

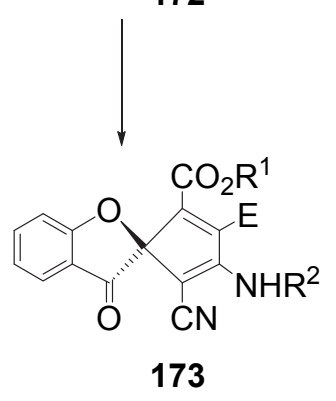

Scheme 26 
When 3-cyanochromone $\mathbf{1}$ as well its analogue having its benzene ring mono- or disubstituted with chlorine or methyl group is reacted with 2 equivalents each of alkyne $\mathbf{1 6 8}$ and isonitrile 169, in toluene at $40{ }^{\circ} \mathrm{C}$ for $12 \mathrm{~h}$, the spirochromeno derivative $\mathbf{1 7 5}$ or 176 (but never a mixture of the two) is obtained in 60-80\% yield (Scheme 27). ${ }^{69}$ Of all the unsubstituted and different mono- and di-substituted 3-cyanochromones used in this five component reaction, only 1a-d can form the spirocompound 176 and that too only with $168\left(\mathrm{E}=\mathrm{CO}_{2} \mathrm{Me}, \mathrm{R}^{1}=\mathrm{Me}\right)$ and $169\left(\mathrm{R}^{2}=t-\mathrm{Bu}\right)$. The nucleophilic end of the zwitterions 170 attacks preferentially $\mathrm{C}-2$ of chromone 1 leading to the intermediate 174. Before its collapse to 171, the dipolar ion intermediate $\mathbf{1 7 4}$ is captured by a second dipolar molecule $\mathbf{1 7 0}$ to give the spirocompound $\mathbf{1 7 5}$. If the initial attack of $\mathbf{1 7 0}$ at pyran C-2 occurs from the up side of the chromone ring leading to the energetically activated intermediate 174, the next attack of a second molecule of $\mathbf{1 7 0}$ to the chromone-4-carbonyl would preferentially take place from the opposite (i.e. down side) of the chromone ring; hence the product should assume the stereochemical feature as depicted in the structure 175, a 1,3-hydride shift in $\mathbf{1 7 5}$ leading to 176. The reason for only a few members of $\mathbf{1 7 5}$ isomerising to $\mathbf{1 7 6}$ is not ascertained. The compound $\mathbf{1 7 5}$ is very susceptible to acid; addition of a catalytic amount of $p$-toluenesulfonic acid ( $2 \mathrm{~mol} \%$ ) in toluene converts 175 to 177 in $71-90 \%$ yield. $^{69}$
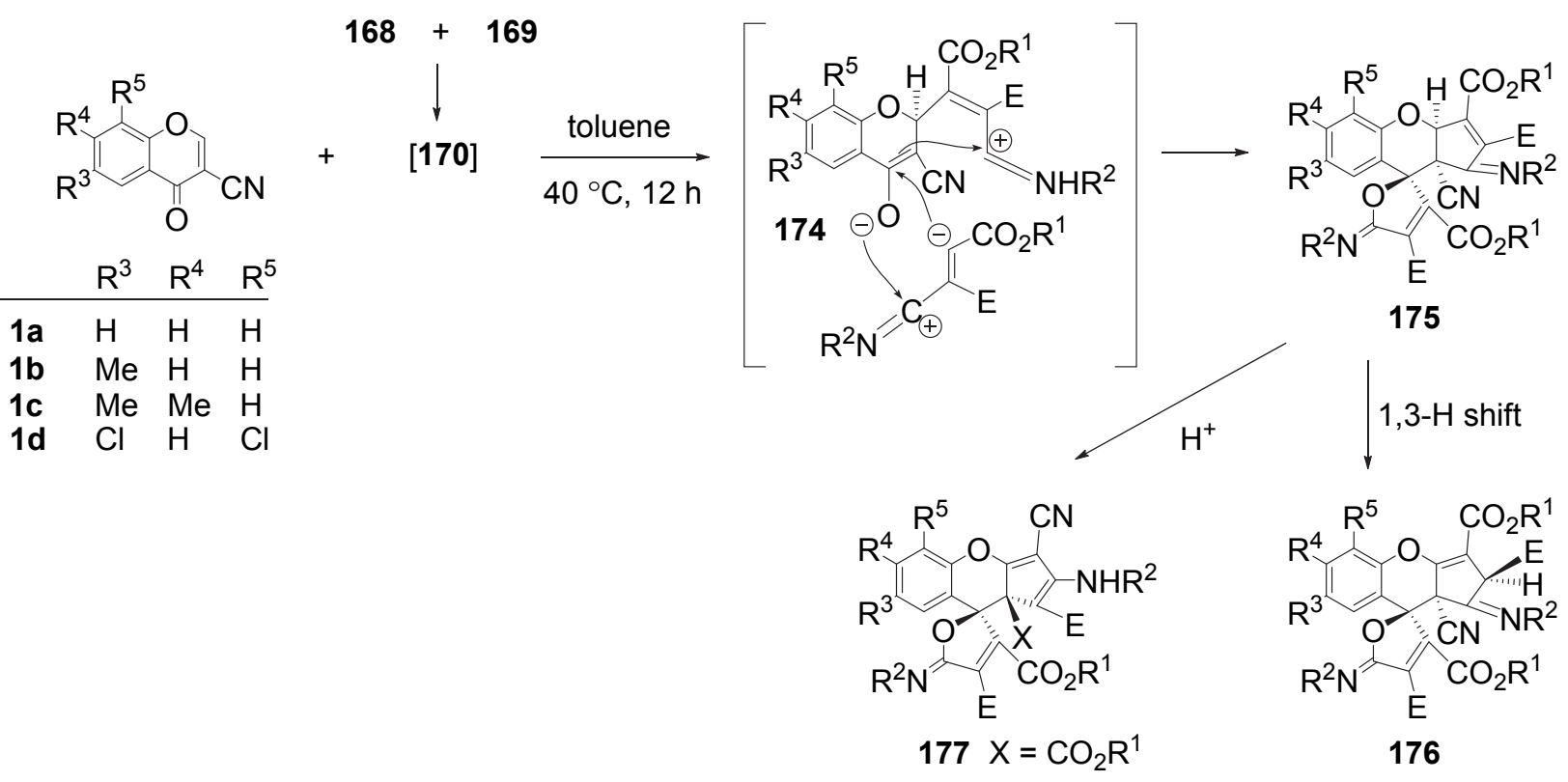

\section{Scheme 27}

\section{Carbocyanation of Alkyne with 3-Cyanochromone}

Nickel - Lewis acid catalyzed hetaryl cyanation of 4-octyne 178 with 3-cyanochromone 1 to the disubstituted octene 179 in $Z$-isomeric form (Scheme 28) is known. ${ }^{70}$ The reaction has been carried out using $\mathrm{Ni}(\text { cyclooctadiene })_{2}(40 \mu \mathrm{mol})$ 1,4-bis(diphenylphosphino)butane $(40 \mu \mathrm{mol})$ as 
ligand and triphenylborane as the Lewis acid catalyst in toluene at $80^{\circ} \mathrm{C}$ for $20 \mathrm{~h}$ to give the product in $91 \%$ yield. A plausible mechanism of this carbocyanation has also been proposed. ${ }^{70}$

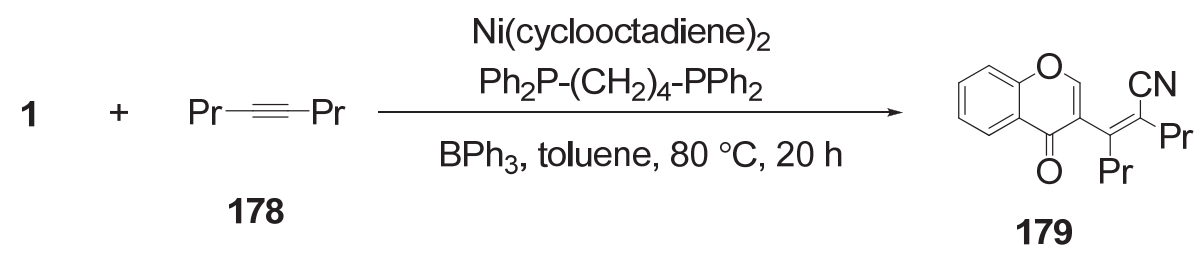

For 178 and $179: \operatorname{Pr}=n$-propyl

\section{Scheme 28}

\section{Conclusions}

Publications mainly during 2005 to 2014 on the chemistry of 3-cyanochromone and its use as a synthon for several novel heterocycles have been comprehended. This review article together with an earlier one ${ }^{1}$ is likely to provide a quick overview of the work already done in the title topic.

\section{References}

1. Ghosh, C. K.; Karak, S. K. J. Heterocycl. Chem. 2005, 42, 1035-1042. http://dx.doi.org/10.1002/jhet.5570420601

2. Ghosh, C. K.; Bandyopadhyay, C.; Maiti, J. Heterocycles 1987, 26, 1623-1656. http://dx.doi.org/10.3987/R-1987-06-1623

3. Sosnovskikh, V. Y.; Moshkin, V. S. Chem. Heterocycl. Compd. 2012, 48, 139-146. http://dx.doi.org/10.1007/s10593-012-0977-3

4. Ghosh, C. K.; Chakraborty, A. Arkivoc 2015, (vi), 288-361. http://dx.doi.org/10.3998/ark.5550190.p009.020

5. Nohara, A. Tetrahedron Lett. 1974, 1187-1190. http://dx.doi.org/10.1016/S0040-4039(01)82441-2

6. Klutchko, S.; Cohen, M. P.; Shavel, Jr. J.; von Strandtmann, M. J. Heterocycl. Chem. 1974, 11, 183-188.

http://dx.doi.org/10.1002/jhet.5570110214

7. Nohara, A.; Kuriki, H.; Saijo, T.; Sugihara, H.; Kanno, M.; Sanno, Y. J. Med. Chem. 1977, 20, 141-145. http://dx.doi.org/10.1021/jm00211a030

8. Reddy, G. J.; Latha, D.; Thirupathaiah, C.; Rao, K. S. Org. Prep. Proced. Int. 2004, 36, 287289.

http://dx.doi.org/10.1080/00304940409355968 
9. Hsung, R. P.; Zicsak, C. A.; Wei, L.-L.; Zhender, L. R.; Park, F.; Kim, M.; Tran, T. -T. T. J. Org. Chem. 1999, 64, 8736-8740.

http://dx.doi.org/10.1021/jo991031j

10. Tsuji, C.; Miyazawa, E.; Sakamoto, T.; Kikugawa, Y. Synth. Commun. 2002, 32, 3871-3879. http://dx.doi.org/10.1081/SCC-120015406

11. Reddy, G. J.; Latha, D.; Thirupathaiah, C.; Rao, K. S. Heterocycl. Commun. 2004, 10, 279282.

12. Reddy, G. J.; Latha, D.; Thirupathaiah, C.; Rao, K. S. Tetrahedron Lett. 2004, 45, 847-848. http://dx.doi.org/10.1016/j.tetlet.2003.11.023

13. Anker, T.; Friden-Saxin, M.; Pemberton, N.; Seifert, T.; Grotli, M.; Luthman, K.; Hilmerson, G. Org. Lett. 2010, 12, 2210-2213. http://dx.doi.org/10.1021/ol100424y

14. Zimmerman, J. R.; Manpadi, M.; Spatney, R. Greeen Chem. 2011, 13, 2103-3106. http://dx.doi.org/10.1039/c1gc15775b

15. Ibrahim, M. A. Tetrahedron 2009, 65, 7687-7690. http://dx.doi.org/10.1016/j.tet.2009.06.107

16. Ghosh, C. K.; Tewari, N. J. Org. Chem. 1980, 45, 1964-1968. http://dx.doi.org/10.1021/jo01298a042

17. Ghosh, C. K.; Tewari, N.; Bandopadhyay, C. Indian J. Chem. 1983, 22B, 1200-1204.

18. Sosnovskikh, V. Y.; Moshkin, V. S.; Eltsov, O. S. Russ. Chem. Bull. Int. Ed. 2010, 59, 21512154. http://dx.doi.org/10.1007/s11172-010-0372-0

19. Sosnovskikh, V. Y.; Moshkin, V. S.; Kodess, M. I. Tetrahedron Lett. 2009, 50, 6515-6518. http://dx.doi.org/10.1016/j.tetlet.2009.09.028

20. Ghosh, C. K.; Ghosh, C.; Patra, A. Indian J. Chem. 1998, 37B, 387-390.

21. Risitano, F.; Grassi, G.; Foti, F. J. Heterocycl. Chem. 2001, 83, 1083-1086. http://dx.doi.org/10.1002/jhet.5570380511

22. Abdel-Megid, M. Chem. Heterocycl. Compd. 2009, 45, 1523-1531. http://dx.doi.org/10.1007/s10593-010-0460-y

23. Abdel-Megid, M. J. Chem. Chem. Engineering 2010, 4, 32-40.

24. Abdel-Megid, M.; Ibrahim, M. A.; Gabr, Y.; El-Gohary, N. M.; Mohamed, E. A. J. Heterocycl. Chem. 2013, 50, 615-624.

http://dx.doi.org/10.1002/jhet.1608

25. Ghosh, C. K.; SinhaRoy, D. K.; Mukhopadhyay, K. K. J. Chem. Soc., Perkin Trans 1 1979, 1964-1968.

http://dx.doi.org/10.1039/p19790001964

26. Sosnovskikh, V. Y.; Moshkin, V. S.; Kodess, M. I. J. Heterocycl. Chem. 2010, 47, 629-633.

27. Jerzmanowska, Z.; Basinki, W.; Zielinska, L. Polish J. Chem. 1980, 54, 383-386.

28. Basinski, W.; Jerzmanowska, Z. Polish J. Chem. 1983, 57, 471-481.

29. Sosnovskikh, V. Y.; Moshkin, V. S.; Kodess, M. I. Tetrahedron Lett. 2008, 49, 6856-6859. 


\section{http://dx.doi.org/10.1016/j.tetlet.2008.09.091}

30. Sosnovskikh, V. Y.; Moshkin, V. S. Russ. Chem. Bull. Int. Ed. 2010, 59, 1056-1058. http://dx.doi.org/10.1007/s11172-010-0205-1

31. Ibrahim, M. A. Synth. Commun. 2009, 9, 3527-3545. http://dx.doi.org/10.1080/00397910902788141

32. Ibrahim, S. S.; Allimony, H. A.; Abdel-Halim, A. M.; Ibrahim, M. A. Arkivoc 2009, (xiv), 28-38.

33. Ibrahim, M. A.; Hassanin, H. M.; Gabr, Y. A. -A.; Alnamer, A. -S. Eur. J. Chem. 2010, 1, 195-199.

http://dx.doi.org/10.5155/eurjchem.1.3.195-199.91

34. Ibrahim, M. A; Tetrahedron 2013, 69, 6861-6865. http://dx.doi.org/10.1016/j.tet.2013.06.011

35. Ghosh, C. K.; Tewari, N.; Morin, C. Indian J. Chem. 1982, 21B, 881-882.

36. Abdel-Rahman, A. H.; Hammouda, M. M. A.; El-Desoky, S. I. Heteroatom Chem. 2005, 16, 20-27.

http://dx.doi.org/10.1002/hc.20048

37. Dimitriadou, E.; Raftopoulou, M.; Kasapidou, M.; Tsoleridis, C. A.; StephanidouStephanatou, J.; Hadjipavlou-Litina, D. J.; Kontogiorgis, C.; Pritsa, A.; Papadopoulos, A. Arkivoc 2014, (iv), 372-384. http://dx.doi.org/10.3998/ark.5550190.p008.754

38. Xiang, H.; Chen, J.; Miao, Z.; Yang, C. RSC Adv. 2014, 4, 16132-16135. http://dx.doi.org/10.1039/C4RA01848F

39. Abdel-Rahman, A. -R. H.; Girges, M. M.; El-Ahl, A.-A. S.; Sallam, L. M. Heteroatom Chem. 2006, 17, 2-7.

http://dx.doi.org/10.1002/hc.20152

40. Ghosh, C. K.; Sahana, S. Indian J. Chem. 1996, 35B, 203-206.

41. Kornev, M. Y.; Moshkin, V. S.; Eltsov, O. S.; Sosnovskikh, V. Y. Chem. Heterocycl. Compd. 2013, 48, 1565-1567. http://dx.doi.org/10.1007/s10593-013-1175-7

42. Langer, P.; Appel, B. Tetrahedron Lett. 2003, 44, 5133-5135. http://dx.doi.org/10.1016/S0040-4039(03)01030-X

43. Langer, P. Synlett 2007, 1016-1025. http://dx.doi.org/10.1055/s-2007-973894

44. Adeel, M.; Rashid, M. A.; Rasool, N.; Ahmad, R.; Villinger, A.; Reinke, H.; Fischer, C.; Langer, P. Synthesis 2009, 243-250.

45. Reim, S.; Adeel, M.; Hussain, I.; Yawer, M. A.; Ahmed, Z.; Villinger, A.; Langer, P. Tetrahedron Lett. 2008, 49, 4901-4904. http://dx.doi.org/10.1016/j.tetlet.2008.05.151

46. Adeel, M.; Reim, S.; Wolf, V.; Yawer, M. A.; Hussain, I.; Villinger, A.; Langer, P. Synlett 2008, 2629-2632. 
47. Appel, B.; Saleh, N. N. R.; Langer, P. Chem. Eur. J. 2006, 12, 1221-1236.

\section{http://dx.doi.org/10.1002/chem.200501024}

48. Rashid, M. A.; Rasool, N.; Appel, B.; Adeel, M.; Karapetyan, V.; Mkrtchyan, S.; Reinke, H.; Fischer, C.; Langer, P. Tetrahedron 2008, 64, 5416-5425.

http://dx.doi.org/10.1016/j.tet.2008.02.105

49. Ibad, M. F.; Abid, O.-ur-R.; Adeel, M.; Nawaz, M.; Wolf, V.; Villinger, A.; Langer, P. J. Org. Chem. 2010, 75, 8315-8318.

http://dx.doi.org/10.1021/jo1018443

50. Karapetyan, V. A.; Hayastani Kim. Handes 2008, 61, 210-215.

51. Patil, N. T.; Huo, Z.; Yamamoto, Y. J. Org. Chem. 2006, 71, 6991-6995.

http://dx.doi.org/10.1021/jo061110c

52. Dieskau, A. P.; Holzwarth, M. S.; Plietker, B. Chem. Eur. J. 2012, 18, 2423-2429.

http://dx.doi.org/10.1002/chem.201103009

53. Al Houari, G.; El Fazazi, A.; Filali Baba, B.; Filali Baba, M.; El Yazidi, M.; Benani, B.; Ben Larbi, N.; Kerbal, A. Phys. Chem. News 2008, 42, 128-132.

54. Knight, J. G.; Stoker, P. A.; Tchabaneko, K.; Harwood, S. J.; Lawrie, K. W. Tetrahedron 2008, 64, 3744-3750.

http://dx.doi.org/10.1016/j.tet.2008.02.019

55. Cordaro, M.; Grassi, G.; Risitano, F.; Scala, A. Tetrahedron 2010, 66, 2713-2717.

http://dx.doi.org/10.1016/j.tet.2010.02.009

56. Sosnovskikh, V. Y.; Kornev, M. Y.; Moshkin, V. S. Tetrahedron Lett. 2014, 55, 212-214.

http://dx.doi.org/10.1016/j.tetlet.2013.10.154

57. Hsung, R. P. J. Org. Chem. 1997, 62, 7904-7905.

http://dx.doi.org/10.1021/jo971479p

58. Granum, K. A.; Markel, G.; Mulder, J. A.; Debnis, S. A.; Hsung, R. P. Tetrahedron Lett. 1998, 39, 9597-9600.

http://dx.doi.org/10.1016/S0040-4039(98)02333-8

59. Hsung, R. P. Heterocycles 1998, 48, 421-425.

http://dx.doi.org/10.3987/COM-97-8064

60. Degen, S. J.; Mueller, K. L.; Shen, H. C.; Mulder, J. A.; Golding, G. M.; Wei, L. -L. Zificsak, C. A.; Hsung, R. P. Biorg. Med. Chem. Lett. 1999, 9, 973-978.

http://dx.doi.org/10.1016/S0960-894X(99)00115-8

61. Valiulin, R. A.; Kutateladze, A. G. Tetrahedron Lett. 2010, 51, 3803-3806. http://dx.doi.org/10.1016/j.tetlet.2010.05.078

62. Valiulin, R. A.; Arisco, T. M.; Kutateladze, A. G. J. Org. Chem. 2011, 76, 1319-1332. http://dx.doi.org/10.1021/jo102221q

63. Albrecht, L.; Acosta, E. C.; Fraile, A.; Albrecht, A.; Christensen, J.; Jorgensen, K. A. Angew. Chem. Int. Ed. 2012, 51, 9088-9092.

http://dx.doi.org/10.1002/anie.201204790 
64. Sosnovskikh, V. Y.; Irgashev, R. A.; Demkovich, I. A. Russ. Chem. Bull. Int. Ed. 2008, 57, 2210-2213.

http://dx.doi.org/10.1007/s11172-008-0304-4

65. Yan. J.; Cheng, M.; Hu, F.; Hu, Y. Org. Lett. 2012, 14, 3206-3209.

http://dx.doi.org/10.1021/o13013099

66. Patil, N. T.; Huo, Z.; Yamamoto, Y. Tetrahedron 2007, 63, 5954-5961.

http://dx.doi.org/10.1016/j.tet.2007.02.110

67. Patil, N.; Yamamoto, Y. Synlett 2007, 1994-2005.

68. Zarganes-Tzitzikas, T.; Terzidis, M. A.; Stephanidou-Stephanatou, J.; Tsolerdis, C. A.; Kostakis, G. E. J. Org. Chem. 2011, 76, 9008-9014.

http://dx.doi.org/10.1021/jo201732g

69. Terzidis, M. A.; Zarganes-Tzitzikas, T.; Tsimenidis, C.; Stephanidou-Stephanitou, J.; Tsoleridis, C. A.; Kostakis, G. E. J. Org. Chem. 2012, 77, 9018-9028.

http://dx.doi.org/10.1021/jo3014947

70. Yada, A.; Ebata, S.; Idei, H.; Nakao, Y.; Hiyama, T. Bull. Chem. Soc. Jpn. 2010, 83, 11701184.

http://dx.doi.org/10.1246/bcsj.20100068

\section{Authors' Biographies}

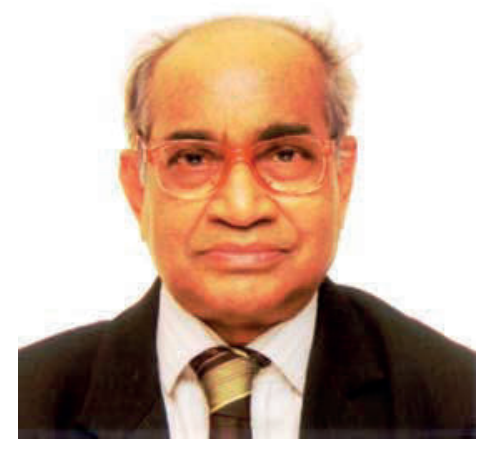

Chandra Kanta Ghosh got from the University of Calcutta his M.Sc., Ph.D. and D.Sc. degrees in Chemistry in 1965, 1970 and 1996, respectively. He did his postdoctoral research in the Department of Organic Chemistry, Karlsruhe University, Germany (1973-74) and in the Biology Division of Oak Ridge National Laboratory, USA (1979-80). He was a faculty member in Organic Chemistry Section in the Department of Biochemistry, Calcutta University during 19692007. Even after his formal retirement as a Professor in 2007, Dr. Ghosh has been contributing to many journals. His research interest lies mainly in the chemistry of 1-benzopyran-4-one (chromone) having an electron withdrawing group at its 3-position. He has so far sixty five publications in this field. 


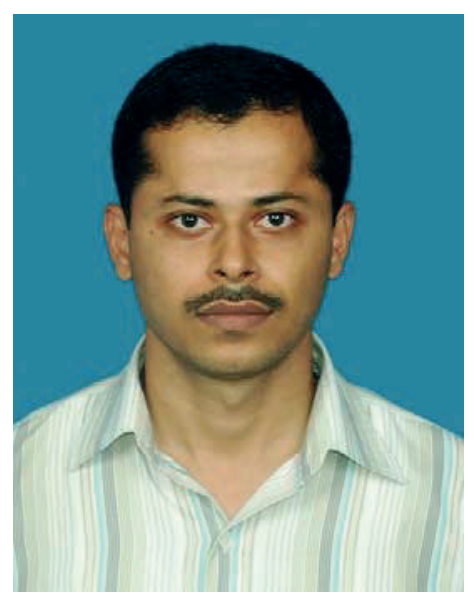

Amarnath Chakraborty received his B.Sc. and M.Sc. in Chemistry from Vidyasagar University, India in 2002 and 2004 respectively. After obtaining Ph.D. in 2011 for his work on organometallic chemistry with Professor Amitabha Sarkar in Indian Association for the Cultivation of Science (IACS), Kolkata, he moved to Radboud University, Netherlands for his postdoctoral research with Professor Jan C. M. van Hest. Then he joined the laboratory of Professor Amitabha Sarkar as a Research Associate in the Department of Organic Chemistry at IACS, Kolkata. Currently he is an Assistant Professor at the Department of Basic Sciences and Humanities in Institute of Engineering \& Management (IEM), Salt Lake, Kolkata, India. His current research interest is focused on synthetic organic and organometallic chemistry as well as synthesis of novel heterocycles from 1-benzopyran-4-one system. 